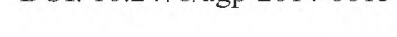

\title{
Triassic-Jurassic flora of Poland; floristical support of climatic changes
}

\author{
MARIA BARBACKA ${ }^{1,2}$, GRZEGORZ PACYNA ${ }^{3}$, ANNA FELDMAN-OLSZEWSKA ${ }^{4}$, \\ JADWIGA ZIAJA ${ }^{1}$ AND EMESE BODOR ${ }^{5,6}$ \\ ${ }^{1}$ W. Szafer Institute of Botany, Polish Academy of Sciences, ul. Lubicz 46, PL-31-512 Kraków, Poland. \\ E-mail:maria.barbacka@gmail.com,j.ziaja@botany.pl \\ ${ }^{2}$ Department of Botany, Hungarian Natural History Museum, H-1476 Budapest, P.O. Box 222, Hungary. \\ E-mail: barbacka@bot.nhmus.hu \\ ${ }^{3}$ Department of Palaeobotany and Palaeoherbarium, Institute of Botany, Jagiellonian University, ul. Lubicz 46, \\ PL-31-512 Kraków, Poland. E-mail: grzegorz.pacyna@uj.edu.pl \\ ${ }^{4}$ Polish Geological Institute National Research Institute, ul. Rakowiecka 4,PL-00-975 Warszawa, Poland. \\ E-mail: anna.feldman-olszewska@pgi.gov.pl \\ ${ }^{5}$ Department of Palaeontology, Eötvös Loránd University, Pázmány Péter sétány 1/C, H-1117 Budapest, Hungary. \\ E-mail: emesebodor@gmail.com \\ ${ }^{6}$ Geological and Geophysical Collections, Hungarian Geological and Geophysical Institute, Stefänia ủt 14, \\ Budapest, H-1143 Hungary
}

\begin{abstract}
:
Barbacka, M., Pacyna, G., Feldman-Olszewska, A. Ziaja, J.and Bodor, E. W. 2014. Triassic-Jurassic flora of Poland; floristical support of climatic changes. Acta Geologica Polonica, 64 (3), 281-309. Warszawa.

Plant macroremains from five boreholes in Poland were studied. Two of them (Huta OP-1 and Studzianna) from the northern margin of the Holy Cross Mountains, yielded several taxa. In the other three boreholes determinable fossil plants were sporadic, albeit important. Most of the taxa from the Huta OP-1 and Studzianna boreholes are typical of the European Early Jurassic (Hettangian and Sinemurian). Both localities, although close to one another, show quite different taxonomic floral compositions. The Huta OP-1 flora is fern-dominated with the presence of ginkgophytes and conifers (a new species incertae sedis, Desmiophyllum harrisii Barbacka et Pacyna is herein proposed), which would suggest rather wet and warm conditions. This flora is typical of the European Province of the EuroSinian Region. In Studzianna the Siberian elements dominate, gymnosperms, mainly Czekanowskiales, which indicate a drier and colder environment. The palaeobotanical data correspond to the results of clay mineral studies, in particular the kaolinite/illite ratio in the source formations. The kaolinite content confirms a decrease in temperature and a reduction in rainfall in the late Early Hettangian and the latest Hettangian in the area.
\end{abstract}

Key words: Triassic; Jurassic; Poland; Macroflora; Desmiophyllum harrisii sp. nov.; Palaeoclimate.

\section{INTRODUCTION}

In Poland, the Mesozoic fossil plants have been successively studied since the $19^{\text {th }}$ century. Apart from richly fossiliferous classic Jurassic localities, like Grojec, Chmielów and Gromadzice (Pacyna 2013), there are several small outcrops and boreholes in different parts of the country which are still under study. A report on current work on some of the boreholes is the aim of the present paper. It includes both taxonomic description of plant remains and discussion of inferred local conditions, landscapes, climatic and environmental changes. 
The presented plant macroremains are from five boreholes: Studzianna and Huta OP-1 (northeast margin of the Holy Cross Mountains), Ciechocinek IG 1 and Brześć Kujawski IG 3 (central Poland), and Chabowo 2 (Szczecin region, northwest Poland). Of these, only the Studzianna and Huta OP-1 boreholes yielded relatively rich material (fourteen and twelve taxa respectively); the other three yielded determinable specimens sporadically.
The Studzianna and Huta OP-1 boreholes are situated in the marginal part of the Holy Cross Mountains, which is the largest Lower Jurassic outcrop area in extra-Carpathian Poland. Several localities with floral remains have been discovered and investigated in this region, with a number of geological, sedimentological and geochemical studies undertaken (Karaszewski 1962; Karaszewski and Kopik 1970; Pieńkowski 1983, 2004; Brański 2009, 2011). The richest flora was re-

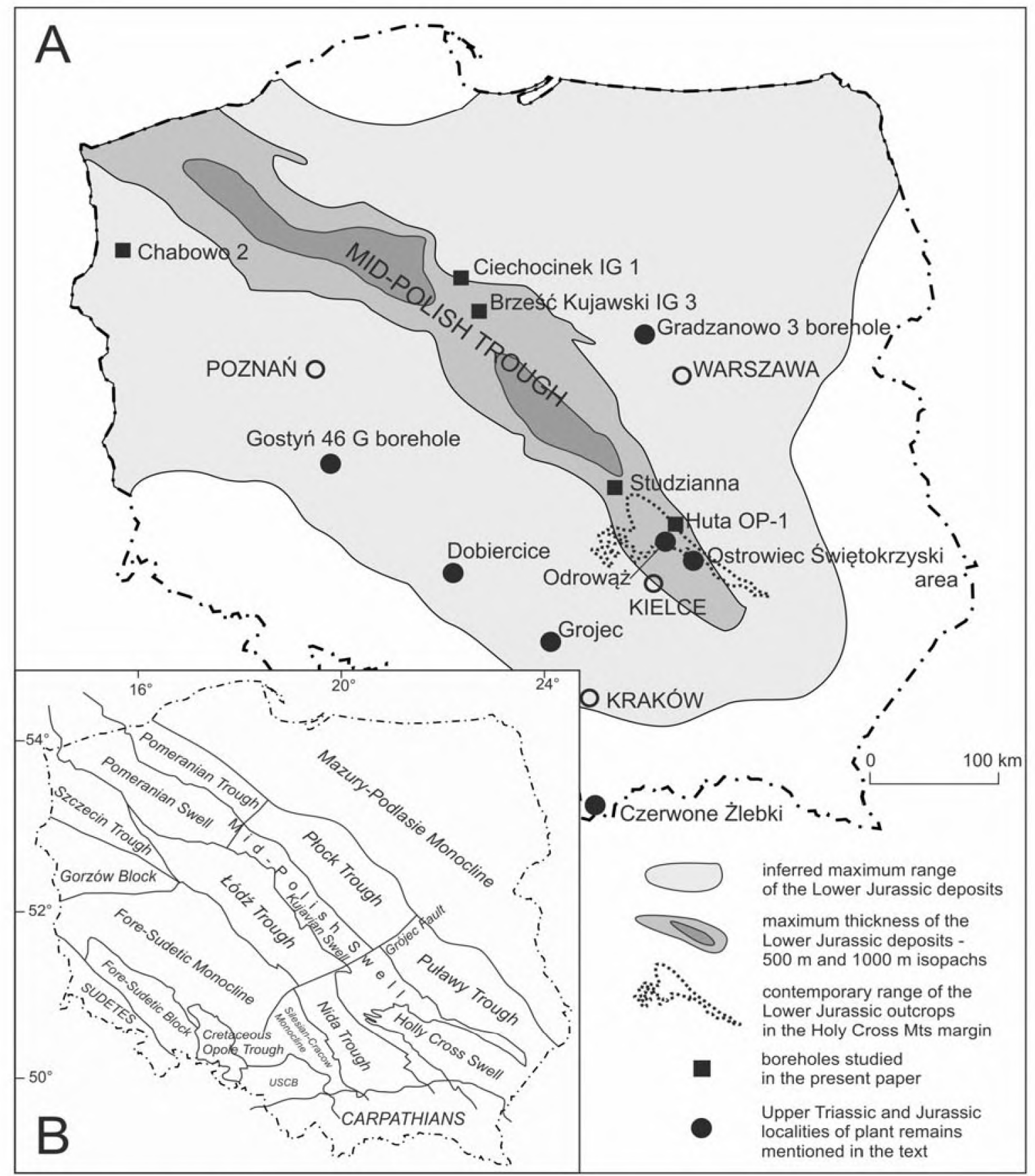

Text-fig. 1. Distribution of the studied boreholes and outcrops mentioned in the paper (A after Pieńkowski 2004 and B after Narkiewicz and Dadlez 2008; modified). Localities of Ostrowiec Świẹtokrzyski area: Chmielów, Gromadzice, Jędrzejowice, Miłków, Mnichów, Podszkodzie, Szewna 
ported from the locality of Odrowąż (Reymanówna 1992; Wcisło-Luraniec 1992; Ziaja 2006; Barbacka et al. 2007; Barbacka et al. 2010). All of the taxa reported so far from this region suggested a wet and warm environment, and the observed plant diversity could easily be explained in terms of local environmental changes in landscape type and distance from fresh water (Barbacka et al. 2010).

The results reported herein provide new data on late Early-Middle Hettangian floristical changes which suggest drastic local climate fluctuations well in accord with the geochemical data.

\section{GEOLOGICAL SETTING}

(by Anna Feldman-Olszewska)

The studied material comes from boreholes located within the axial, most subsiding and later inverted part of the Polish epicontinental basin, the so called Mid-Polish Trough. The sampled boreholes are: Huta OP-1 and Studzianna in the southeastern part of the area (northern margin of the Holy Cross Mountains); Brześć Kujawski IG 3 and Ciechocinek IG1 in the middle part of the area (Kuiavian segment); and Chabowo 2, located in the northwestern part of the area (western part of the Szczecin Synclinorium) (Textfig. 1). The Upper Triassic and Lower Jurassic deposits in the axial part of the basin are about $1400 \mathrm{~m}$ thick. The succession represents a variety of environments, from terrestrial (fluvial, lacustrine, swamps, sebkha) through brackish (bay, deltaic, coastal plain) to shallow marine (shoreface) (Gajewska 1978, 1997a, b; Pieńkowski 1983, 2004).

The oldest material studied is of Ladinian (Early Keuper) age. It comes from the Studzianna borehole (depth: $1657.0 \mathrm{~m}$; see Text-fig. 2). The Ladinian part of the Studzianna borehole succession represents the marginal part of a shallow inland basin (Gajewska 1997b) recorded by grey and dark grey claystones and mudstones, with mica, bivalves, fish teeth and abundant, often pyritized, floral remains. The flora of the uppermost Triassic was found in the Chabowo 2 borehole, in light grey massive claystones with dispersed mica and numerous plant fragments. These are probably braided river deposits of either the uppermost Zbąszynek beds or of the Wielichowo beds (Rhaetian).

The most fossiliferous unit is the Lower Hettangian Zagaje Formation which is well represented in the Huta OP-1 and Studzianna boreholes (Text-figs 1, 2). The formation is dominated by continental deposits (Pieńkowski 1983). Its basal part is represented by sandstones of a meandering river depositional system
(Pieńkowski 2004, fig. 21). The sandstones are quickly replaced upward by meandering river floodplain and then lacustrine-swamp fine-grained deposits (Text-fig. 2) with abundant plant remains and root horizons. Less frequent are coal layers, desiccation cracks and sideritic concretions.

A Late Hettangian flora was found only in the Przysucha Ore-bearing Formation in the Studzianna borehole (depth $862.6 \mathrm{~m}$ ), (Text-fig. 2). This formation is characterized by shallow marine depositional systems and marginal continental systems (lagoonal, barrier, deltaic and lacustrine deposits, and subordinately by shoreface deposits) (Pieńkowski 2004). Karaszewki (1962) reported Czekanowskia remains from this part of the succession. Still younger, the Ostrowiec Formation (Sinemurian), is known from the Studzianna and Brześć Kujawski IG 3 boreholes. The lower part of the formation represents an alluvial depositonal system. It is composed of river channel sandstone and mudstone with abundant remains of plants that grew in the flood plain / lacustrine environments. The middle and upper parts of this formation are dominated by brackish-shallow marine sandstone and mudstone interbedded by lagoonal, barrier and deltaic deposits (Pieńkowski 2004). In both boreholes floral remains were found in the lower part of the formation. Samples from the Studzianna borehole (depths 768.0-771.0 m; 772.0 m; 783.0 m) are composed of heteroliths with wavy and lenticular bedding, and represent an alluvial floodplain depositional system. Plant fragments from the Brześć Kujawski IG 3 borehole (depth $2190.05 \mathrm{~m}$ ) derive from dark grey mudstone with plant roots of flood plain / lake environment (Feldman-Olszewska 2008a, b).

The youngest material comes from the plant-rich, floodplain claystones of the Upper Toarcian Borucice Formation (depth $972.7 \mathrm{~m}$ ) of the Ciechocinek IG 1 borehole. The formation is composed mostly of fluvial sandstones, less frequently of fine-grained deposits, mostly channel fill deposits in the lower part, and crevasse splay and floodplain deposits in the upper part.

\section{MATERIAL AND METHODS}

The examined material comes from five boreholes and displays wide variation in state and preservation. Generally, of more than 300 samples containing plant macroremains only about 140 were suitable for examination; the rest of the samples were strongly fragmented (suggesting high energy transport), but the degree of fragmentation differs depending on the locality. In most localities, the plant remains are preserved as coalified compressions; in some cases, only impressions are pres- 


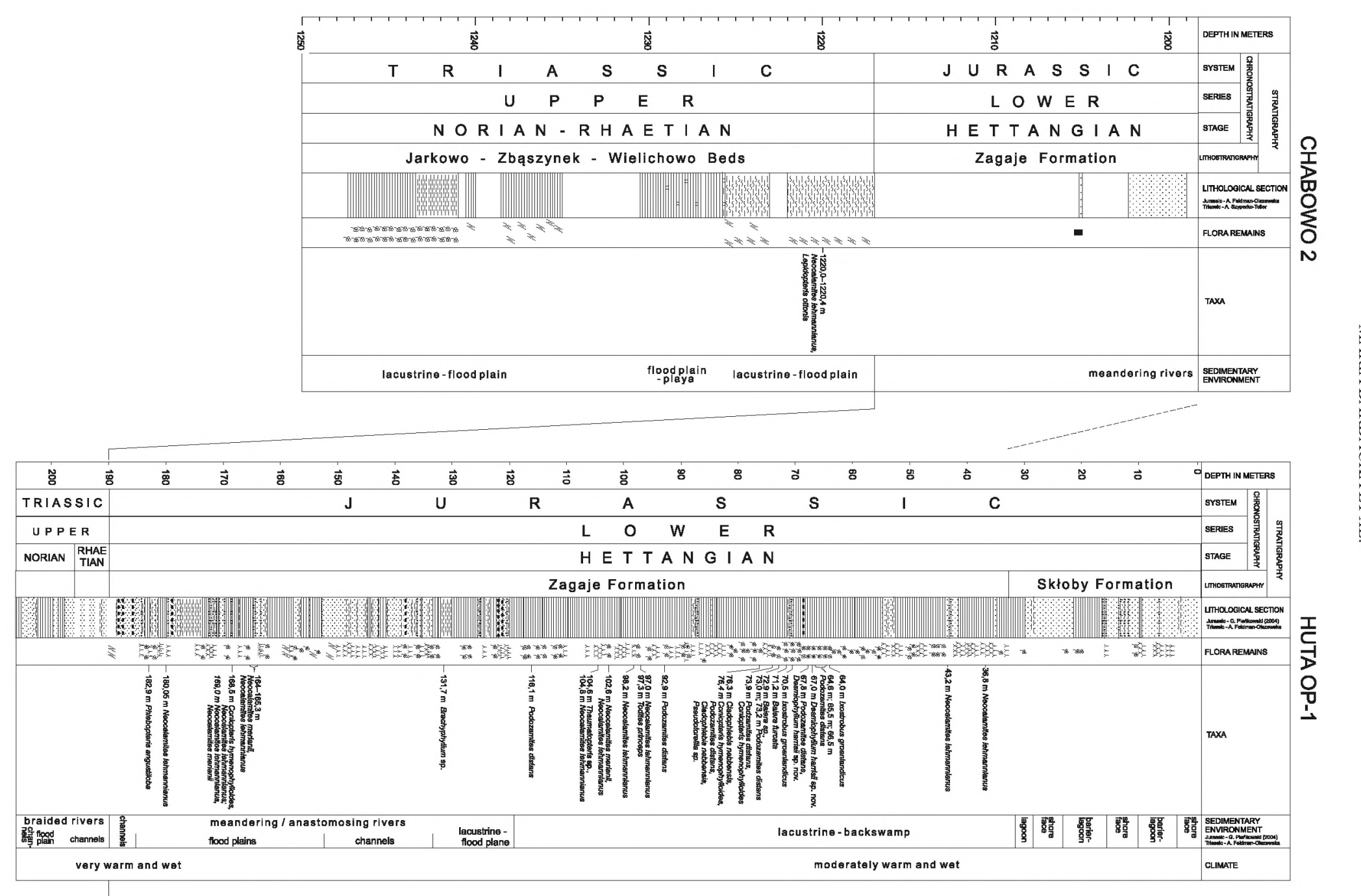


TRIASSIC-JURASSIC FLORA OF POLAND

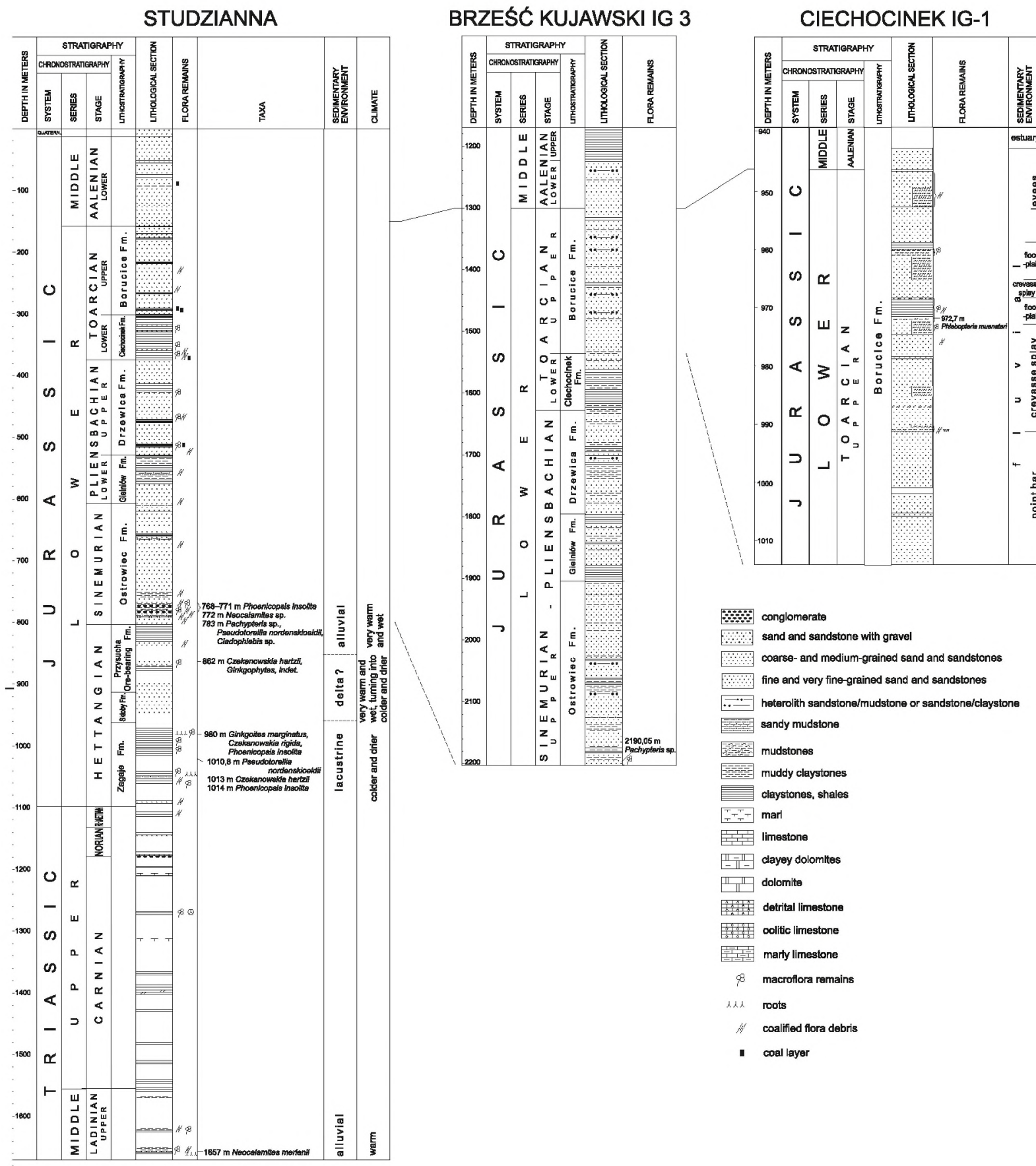


ent. Because of the core diameter (between 8.5 and 11.5 $\mathrm{cm}$ ) larger plants are available only in fragments. Cuticles are usually very poorly preserved, and are only rarely suitable for maceration.

The cuticles were cleaned by maceration in Schulze solution, and then washed with $3 \% \mathrm{KOH}$. They were studied using light and fluorescent microscopy.

The material studied is stored in the W. Szafer Institute of Botany of the Polish Academy of Sciences in Kraków (KRAM-P PM) and in the Polish Geological Institute - National Research Institute in Warszawa (Muz. Geol. PIG)

The litostratigraphic scheme used herein is based on Pieńkowski (2004, fig. 3).

\section{SYSTEMATIC DESCRIPTIONS}

Taxonomy is given according to Meyen (1987) and Anderson et al. (2007).

Division Equisetophyta Scott, 1900

Order Equisetales de Candolle ex von Berchtold et Presl, 1820

Family incertae sedis Genus Neocalamites Halle, 1908

TYPE SPECIES: Neocalamites lehmannianus (Goeppert, 1846) Weber, 1968 (=Neocalamites hoerensis (Schimper, 1869) Halle, 1908 sensu Halle 1908)

\section{Neocalamites lehmannianus (Goeppert, 1846) \\ Weber, 1968 \\ (Pl. 1, Figs 1-3)}

1840. Calamites hoerensis n. sp., Hisinger, p. 5, pl. 38, fig. 8 .

1846. Calamites Lehmannianus n. sp. Goeppert, p. 143, pl. 1 , figs 1-3.

1869. Schizoneura hoerensis n.sp. Schimper, vol. 1, pp. 283284.

1908. Neocalamites hoerensis (Schimper) Halle; Halle, pp. 613, pl. 1, 2.

1931. Neocalamites hoerensis (Schimper) Halle; Harris, pp. 22-25, 29, text-fig. 4 A, B.

1961. Neocalamites hoerensis (Schimper) Halle; Harris, pp. 30-33, text-fig. 8 .

1968. Neocalamites lehmannianus (Goeppert) Weber; Weber, pp. 31-39, pl. 1, figs 17-23, pl. 2, figs 25-27, text-figs 4, 5.

2010. Neocalamites lehmannianus (Goeppert) Weber; Barbacka et al. p. 375, pl. 1, fig. 1.

2011. Neocalamites lehmannianus (Goeppert) Weber; Pott and McLoughlin, pp. 1027, 1028, text-fig. 3 C-E.
MATERIAL: KRAM-P PM: 139/124 I, 169.0 m; 139/215+241 (part and counterpart), 43.20-43.60 m; 139/226 (depth $102.6 \mathrm{~m}$ ), 139/148 (depth $169.0 \mathrm{~m}$ ), $139 / 172$ (depth $169.0 \mathrm{~m}$ ), 139/230 (depth $102.6 \mathrm{~m}$ ), 139/256 I+II+III (depth 36.80-37.20 m), 139/306 (depth $97 \mathrm{~m}$ ), 139/313 (depth $98.2 \mathrm{~m}$ ), 139/314 (depth $104.8 \mathrm{~m}$ ), 139/333+339 (part and counterpart), 171.8-172.8 m; 139/334 (part and counterpart), 168.5-169.5 m; 139/335, 164-165.3 m; 139/340, 179.8-180.8 m, all from the Huta OP-1 borehole, Zagaje Formation, Hettangian, Lower Jurassic; Muz. Geol. PIG 1794.II.3, 1220.0 m, Chabowo 2 borehole, Rhaetian, Upper Triassic.

DESCRIPTION: The shoots have recognizable nodes and internodes and are longitudinally ribbed. Internodes are 12 to at least $50 \mathrm{~mm}$ wide; the size of fragments and their length is restricted by the diameter of the core ( 75 $\mathrm{mm})$. The ribs are flat, 0.8 to $1 \mathrm{~mm}$ wide, with a density of 8-10 per $1 \mathrm{~cm}$ (Pl. 1, Fig. 1). Slight longitudinal striae are visible on the ribs (Pl. 1, Fig. 1). The ribs run straight through the node. On the nodes, circular leaf scars are visible on every second rib (Pl. 1, Fig. 2). Leaves are not preserved. Some stems are broken at nodes so their internal structure is visible in cross section. The stem at the node is 20 to $30 \mathrm{~mm}$ in diameter. In the central part of the node the pith canal is visible; there is a narrow ring of small, barely visible vascular bundles on its margin, and next to it the wider ring of cortex with numerous and densely spaced vallecular canals. Each canal is $5 \mathrm{~mm}$ long and 2 mm wide (Pl. 1, Fig. 3).

DISCUSSION: Neocalamites lehmannianus, as understood herein, has a long and complicated history. The species Calamites Lehmannianus Goeppert was established originally for two specimens (wide and narrow shoot) from the locality of Dobiercice (Wilmsdorf in the original paper) in Upper Silesia (Goeppert 1846). Another species, Calamites hoerensis, was established by Hisinger (1840). Schimper (1869) gave its emended diagnosis under the name Schizoneura hoerensis (without illustrating this species), which was widely accepted (e.g., Nathorst 1878a, b, and Halle 1908). Halle (1908) created the new genus Neocalamites, with Neocalamites hoerensis sensu Schimper (1869) and Nathorst (1878a, b) as its type species. Halle (1908) found and illustrated Hisinger's (1840) types but considered them indeterminable, and suggested that they might belong to the species Equisetites scanicus (?). N. hoerensis, as described and illustrated by Halle (1908) was accepted and used by later authors (Harris 1926, 1931, 1961; Weber 1968). Harris $(1926,1931)$ described and illustrated this species from Greenland and compared it with his new species Neocalamites carcinioides. 
Based on the text of Halle (1908), Harris (1961) thought that Hisinger's specimens did not belong to $N$. hoerensis sensu Halle and emended the diagnosis of Neocalamites hoerensis (Schimper) Halle. He included in this species, albeit provisionally, his specimens from Yorkshire, in northeastern England.

Goeppert (1846) considered that his new species was very similar to Calamites hoerensis (Hisinger 1840). Halle (1908) believed that the two species were different. Weber (1968) revised both species during his work on the Rhaetian-Liassic flora of Germany and synonymized Neocalamites hoerensis sensu Halle (1908) with Calamites Lehmannianus Goeppert, and referred it to the genus Neocalamites.

Unfortunately, the original specimens of Goeppert (1846) have never been photographed and/or revised, and their whereabouts are not known.

In the material from the Huta OP-1 borehole, thin shoots ca. $12 \mathrm{~mm}$ wide dominate. They correspond to specimens illustrated by Halle (1908). However, the expanded nodes mentioned by Halle are not observed. Wider shoots, about $50 \mathrm{~mm}$ wide, are fragmented and correspond to the wide shoot of Goeppert (1846). The specimen from the Chabowo 2 borehole is also Rhaetian in age, like Goeppert's type specimens. Pott and McLoughlin (2011) illustrated for the first time the stem cross section of this species, which is identical to those in our material.

Neocalamites lehmannianus is common in the European floras, ranging from the Upper Triassic to the Middle Jurassic (Harris 1961). In Poland, the species is known from Dobiercice, from where it was originally described by Goeppert (1846) and reported subsequently by Roemer (1870). It was also described, albeit referred to Schizoneura hoerensis, by Raciborski (1890) from the Rhaetian flora of Czerwone Żlebki (the Tatra Mountains) and later (Raciborski 1892) from Miłków, from the Middle Hettangian Skłoby Formation (G. Pieńkowski, pers. comm.). Makarewiczówna (1928), under the name Neocalamites hoerensis Schimper, reported the species from several localities in the Holy Cross Mountains.

Neocalamites merianii (Brongniart, 1828-1837) Halle, 1908

(P1. 1, Figs 4-8)

1828-1837. Equisetum merianii n. sp., Brongniart, p. 115, pl. 12, fig. 13.

1869. Equisetum merianii Brongniart; Schimper, p. 283.

1908. Neocalamites merianii Brongniart; Halle, p. 6.

1958. Neocalamites merianii (Brongniart) Halle; Kräusel, p. 82, pl. 6, fig. 36; pl. 7, figs 38-41; pl. 8, figs 42-43.
1959. Neocalamites merianii (Brongniart) Halle; Kräusel, p. 6, pl. 1, figs 1-7; pl. 2, figs 8-14; text-fig. 1.

1995. Neocalamites merianii (Brongniart) Halle; Kelber and Hansch, p. 48, figs 94, 96, 98-107.

2008. Neocalamites merianii (Brongniart) Halle; Pott et al., pp. 188,190 , pls 3,4 .

MATERIAL: KRAM-PPM 138/15+37 (part and counterpart), $1661 \mathrm{~m}$, Studzianna borehole, Lower Keuper, Upper Ladinian, 139/124 I-II, 169.0 m; 139/225/I+ 226/II (part and counterpart), $102.6 \mathrm{~m} ; 139 / 336,164-$ $165.3 \mathrm{~m}, 139 / 337+338$ (part and counterpart), 164$165.3 \mathrm{~m} ; 139 / 148,169.0 \mathrm{~m}$, all Huta OP-1 borehole, Zagaje Formation, Hettangian, Lower Jurassic.

DESCRIPTION: The material consists of shoot fragments showing nodes and internodes. Their surface is longitudinally ribbed. The internodes are $20-37 \mathrm{~mm}$ wide. Their total length is unknown due to the core diameter. The longest preserved internode is at least $74 \mathrm{~mm}$ long (fragmentary preservation). Nodes are slightly expanded. Ribs are protruding, and are $0.5-0.8 \mathrm{~mm}$ wide, 15 per $10 \mathrm{~mm}$, sometimes grouped in tens in pseudoribs (Pl. 1, Figs 4, 5, 7). The surface of the ribs may be slightly longitudinally striated (P1. 1, Fig. 6, 8). The ribs run straight through the node. Lateral branch scars are round, 8 over the whole width; they are about $2-3 \mathrm{~mm}$ in diameter and touch each other. Leaves are not preserved; leaf scars are very weakly visible, circular, only a few are present on the node, every third rib. The diaphragm is $15 \mathrm{~mm}$ in diameter.

DISCUSSION: Neocalamites merianii (Brongniart) Halle was established by Brongniart (1828) as Equisetum merianii, based on the material from the Keuper of Neuwelt near Basel, Switzerland. The new interpretation of the species was given by Kräusel (1958, 1959), who illustrated numerous well preserved specimens. Pott et al. (2008) gave a detailed description of the species based on material from Lunz (Austria). The investigated material corresponds well to material of Kräusel $(1958,1959)$ and Pott et al. (2008). It is worth noting that in $N$. merianii, in contrast to the extant sphenopsid species, the vascular bundles are not equal in number to the ribs visible on the shoot surface. The shoot surface was covered with wide ribs in a proportion of about 10 vascular bundles to each rib. In the described specimens, the outer surface of the internodes, which is characterized by longitudinal ribs, is clearly marked on the inner surface, which has visible, densely arranged, prominent longitudinal ribs, probably because the coaly layer remaining after the cortex is very thin. This mode of preservation was illustrated by 
Kräusel (1958, 1959) and Kelber and Hansch (1995, fig. 105).

Neocalamites merianii is common in Late Triassic and Early Jurassic floras of Europe (Pott et al. 2008). It has not been previously noted from Poland.

\section{Neocalamites $\mathrm{sp}$.}

(P1. 2, Figs 1, 2)

MATERIAL: KRAM-P PM138/72 I+II, 772.0 m, Studzianna borehole, Ostrowiec Formation, Lower Sinemurian.

DESCRIPTION: The specimen consists of a single fragment of a shoot showing nodes and internodes, covered by ribs. The length of the internode is at least $80 \mathrm{~mm}$ (incompletely preserved; cut by the edge of the core), $8 \mathrm{~mm}$ in width. Ribs are strong, flat, markedly striated, $1 \mathrm{~mm}$ wide, 8 ribs over the whole width of the shoot ( $\mathrm{Pl}$. 2, Figs $1,2)$. The bundles run straight through the node.

DISCUSSION: The specimen is identical in size and morphology to those described by Raciborski (1891, p. 5-6, pl. 1, figs 6, 7.) and referred to Schizoneura hoerensis (Hisinger) Schimper. Raciborski's specimen has a better preserved node, which is well illustrated. The ribs are wider and they are less numerous than in similarly sized $N$. lehamanianus. The age of our specimen is Early Sinemurian. Raciborski's specimen originates from Mnichów near Ostrowiec, probably from the Przysucha Ore-bearing Formation of Late Hettangian age ( $G$. Pieńkowski pers. comm.). It is therefore close in age to that of the specimen from Studzianna. Raciborski also mentioned the same species from the Chmielów Clays, but without illustration. Although our specimen is similar to Neocalamites lehmannianus, it is left in open nomenclature because of missing leaf scar details and differences in stem ribbing.

Division Polypodiophyta Cronquist, Takhtajan and Zimmermann, 1966

Family Osmundaceae Berchtold and J.S. Presl, 1820 Genus Cladophlebis Brongniart, 1849

TYPE SPECIES: Cladoplebis albertsii (Dunker, 1846) Brongniart, 1849

Cladophlebis nebbensis (Brongniart, 1828) Nathorst, 1876

(Pl. 2, Figs 3, 4)
1828. Pecopteris nebbensis n. sp.; Brongniart, p. 299, pl. 98, fig. 3 .

1876. Cladophlebis nebbensis Brongniart; Nathorst, p. 16, pl. 21, figs $1-6$; pl. 3, figs $1-3$.

1922. Cladophlebis nebbensis (Brongniart) Nathorst; Johansson, p. 14, pl. 2, figs 1-3; pl. 7, fig. 7; text-figs 2, 3 .

1964. Cladophlebis nebbensis (Brongniart) Nathorst; Kilpper, p. 59 , pl. 11, figs $8-10$; pl. 12, figs $1,3,6$; pl. 13, fig. 2; pl. 14, fig. 5; text-fig. 35 .

1997. Cladophlebis nebbensis (Brongniart) Nathorst; Schweitzer et al., p. 172, pl. 19, figs 1-5; text-figs 24 B, 26.

MATERIAL: Two specimens with frond fragments; KRAM-P PM: 139/103, 76.3 m; 139/158, 159 (part and counterpart), Huta OP-1 borehole, $76.4 \mathrm{~m}$, all Zagaje Formation, Lower Hettangian.

DESCRIPTION: The rachis of the frond is smooth, 1.7$2 \mathrm{~mm}$ wide. The pinnae arise on the rachis at almost a right angle. The length of the longest preserved pinna fragment is $38 \mathrm{~mm}$. Most of the pinnules are opposite or subopposite, but alternate pinnules also occur (Pl. 2, Figs 3 , 4). In most cases, the pinnule bases are free and the pinnules are slightly elongated with subacute, sometimes rounded, apices. The upper part of the pinnules and apices are often finely dentate (Pl. 2, Fig. 3). Secondary veins dichotomize once near the midrib.

DISCUSSION: The set of features of the studied specimens, i.e., the pinna shape, arrangement of the pinnules, their shape, venation, free bases and dentate apices, allow them to be referred safely to Cladophlebis nebbensis. Our material closely resembles the specimens of Johansson (1922) and Schweitzer et al. (1997).

Cladophlebis sp.

(Pl. 2, Fig. 5)

MATERIAL: One small frond fragment, rachis with 1 pinnule. KRAM-P PM 138/25 VIII, Studzianna borehole, 783 m, Ostrowiec Formation, Lower Sinemurian.

DESCRIPTION: The rachis of the fragment is very thin, $1.2 \mathrm{~mm}$ wide. The pinnule, joined to the rachis at an angle of $65^{\circ}$, is $11 \mathrm{~mm}$ long and $6 \mathrm{~mm}$ wide at its widest point. The apex is subacute and the margins are slightly dentate. Veins arise from the midrib at an angle of ca. $30^{\circ}$ and divide once near their base.

DISCUSSION: The frond fragment is very small, but the size and shape of the pinnule, as well as its venation is 
characteristic of the genus Cladophlebis. The slightly dentate margins and veins dividing once near the midrib correspond well to C. dentata. However, because of the very fragmented nature of the specimen it is left in open nomenclature.

Genus Todites Seward, 1900

TYPE SPECIES: Todites williamsoni (Brongniart 18281838) Seward, 1900

Todites princeps (Presl in Sternberg, 1838) Gothan, $1914 \mathrm{a}$

(P1. 2, Figs 6, 7)

1838. Sphenopteris princeps n. sp. Presl in Sternberg, p. 126, pl. 59, figs $12,13$.

1867. Acroistichites princeps n. sp. Schenk, p. 46, pl. 7, figs 3,4 ; pl. 8 , fig. 1 .

1891. Todea princeps Presl; Raciborski, p. 9, pl. 1, figs 10-13.

1894. Todea princeps Presl; Raciborski, p. 18 (160), pl. 6, figs 22-27.

1914a. Todites princeps Presl; Gothan, p. 95, pl. 17, figs 3, 4.

1926. Todites princeps (Presl) Gothan; Harris, p. 26, pl. 12, fig. 5, text-figs $2 \mathrm{~A}-\mathrm{E}$.

1931. Todites princeps (Presl) Gothan; Harris, p. 35, pl. 11, figs $1,2,4,9 ; \mathrm{pl}$. 12, figs 3 ; text-figs 8,9 .

1961. Todites princeps (Presl) Gothan; Harris, p. 93, text-figs 30, 31 .

1964. Todites princeps (Presl) Gothan; Kilpper, p. 44, pl. 8, figs 6-9; text-fig. 22.

1978. Todites princeps (Presl) Gothan; Schweitzer, p. 31, pl. 1, figs 3-5; pl. 2, figs 4-6; pl. 3, figs 1-7; text-figs 10-18.

1997. Todites princeps (Presl) Gothan; Schweitzer et al., p. 160 , text-fig. $24 \mathrm{~A}$.

2008. Todites princeps (Presl) Gothan; Barbacka and Bodor, p. 134, pl. 1, figs $1-5$.

2010. Todites princeps (Presl) Gothan; Barbacka et al., p. 376 , pl. 1 , figs 7,8 .

MATERIAL: Two small frond remains; one of them is a fragment of a very young frond with part of the rhizome, the second one represents a fragment of the middle part of a frond. KRAM-P PM 139/322 A, B, 97.3 m, Huta OP-1 borehole, Zagaje Formation, Lower Hettangian.

DESCRIPTION: The young plant consists of a transversely compressed rhizome fragment, about $6 \mathrm{~mm}$ in diameter, with remains of four radially compressed sterile fronds (Pl. 2, Fig. 6). One frond is preserved with pin- nules, three are only partially damaged rachises. The rachis is ca. $0.8 \mathrm{~mm}$ wide, the frond fragment is about 25 $\mathrm{mm}$ long. The pinnules are opposite, and nearly oval with wide bases and sphenopterid venation. They are 4.5 mm long near the base of the frond. The longest pinnules are about $7 \mathrm{~mm}$ long and 2-3 $\mathrm{mm}$ wide. The margins of the pinnules near the base of the frond are dissected up to half way up the lamina, forming rounded lobes. Towards the apex of the frond, they are more deeply dissected, almost to the midvein and the lobes become almost separated (Pl. 2, Fig. 7).

DISCUSSION: Todites princeps is common in the Jurassic and is a well defined species displaying wide variability in its pinnules. Harris (1961) described two morphotypes, with dissected and non-dissected pinnules, and a third morphotype, with oval pinnules with crenate margins was reported by Barbacka and Bodor (2008). The species is common in the Mesozoic margin of the Holy Cross Mountains; in its northern part (Raciborski 1891), in the region near Ostrowiec (Makarewiczówna 1928) and in Odrowąż (Barbacka et al. 2010).

Family Dipteridaceae Seward and Dale, 1901 Genus Thaumatopteris Goeppert, 1841-1846

TYPE SPECIES: Thaumatopteris muenesteri Goeppert, $1841-1846$

?Thaumatopteris $\mathrm{sp}$.

(Pl. 2, Fig. 8)

MATERIAL: One very small rachis fragment (12 mm) and incomplete, damaged pinnules; KRAM-P PM 139/219, 221 (part and counterpart), 104.6 m, Huta OP1 borehole, Zagaje Formation, Lower Hettangian.

DESCRIPTION: The specimen shows only a very short piece of the rachis $8 \mathrm{~mm}$ long and $1 \mathrm{~mm}$ wide, and a few remains of pinnules. One fragment of a pinnule, $4.5 \mathrm{~mm}$ long, has preserved a slightly contracted base. The fragment is suggestive of a pinnule elongated in shape with visible midvein and margins that vary from entire to undulated. Secondary veins are not visible.

DISCUSSION: As this specimen is the only fern frond fragment belonging to Dipteridaceae in the studied material, it was worth mentioning. However, its state of preservation made it possible to determine the sample only as ?Thaumatopteris on the grounds of the pinnule shape and base. 
Family Matoniaceae Presl, 1847

Genus Phlebopteris Brongniart, 1828-1837 emend. Harris, 1961

TYPE SPECIES: Phlebopteris polypodioides Brongniart, $1828-1838$

Phlebopteris angustiloba (Presl in Sternberg, 1838) Hirmer et Hörhammer, 1936 (Pl. 3, Fig. 1)

1867. Gutbiera angustiloba Presl; Schenk, p. 64, pl. 18, figs 5-10. 1867. Andriania baruthina Braun; Schenk, p. 87, pl. 21, figs 16.

1891. Laccopteris angustiloba Presl; Raciborski, p. 15, pl. 2, figs 6-9.

1892. Laccopteris angustiloba (Presl) Raciborski; Raciborski, pl. 2, fig. 22.

1931. Laccopteris angustiloba (Presl) Raciborski; Harris, p. 74, pl. 14, figs 6-17, text-fig. 26.

1936. Phlebopteris angustiloba Presl; Hirmer and Hörhammer, p. 26, pl. 6; text-figs 5 (3).

1950. Phlebopteris angustiloba (Presl) Hirmer and Hörhammer; Lundblad, p. 23, pl. 2, fig. 14; pl. 3, figs 1-5, pl. 13, fig. 2; text-fig. 4.

1963. Phlebopteris angustiloba (Presl) Hirmer and Hörhammer; Reymanówna, p. 10, figs 1, 4, 5; text-fig. 1A-E.

1965. Phlebopteris angustiloba (Presl) Hirmer and Hörhammer; Tralau, p. 373, figs A-D.

1993. Phlebopteris angustiloba (Presl) Hirmer and Hörhammer; Van Konijnenburg- van Cittert, p. 241.

2010. Phlebopteris angustiloba (Presl) Hirmer and Hörhammer; Barbacka et al., p. 377, pl. 2, fig. 3.

MATERIAL: Very small fragment of pinnule, $3.5 \mathrm{~mm}$ long; KRAM-PPM 139/326,182.9-184 m, Huta OP-1 borehole, Zagaje Formation, Lower Hettangian.

DESCRIPTION: The fertile pinnule fragment is $2 \mathrm{~mm}$ wide. Four pairs of rounded sori are visible on the lamina. The sori are about $0.6 \mathrm{~mm}$ in diameter. Structural details are not observable.

DISCUSSION: Phlebopteris angustiloba is one of the easiest recognizable ferns due to its very narrow segments with densely arranged, rounded sori in two rows. It is rather rare in Poland, but a small fragment was found in Odrowąż.

Phlebopteris muensteri (Schenk, 1867) Hirmer and Hörhammer, 1936

(P1. 3, Figs 2, 3)
1836. Polypodites Lindleyi n. sp. Goeppert, p. 342, pl. 38, figs 5,6 .

1843. Andriania baruthina var. abbreviata Braun, p. 46, pl. 9 , figs $3,7,8$.

1867. Laccopteris goeppertii n. sp. Schenk, p. 94, pl. 24, figs 2,3 .

1867. Gutbiera angustiloba Presl; Schenk, p. 64, pl. 18, figs $6,8,10$.

1867. Andriania baruthina Braun in Münster; Schenk, p. 87, pl. 24, fig. 1.

1867. Andriania baruthina var. remota Schenk, p. 87, pl. 24 , fig. 1.

1894. Laccopteris mirovensis n. sp. Raciborski, p.182, pl. 12 , figs 22-24.

1914a. Laccopteris sp., Gothan, p. 10, pl. 18, figs 3, 3a.

1919. Gutbiera angustiloba Schenk; Antevs, p.16, pl. 1, figs $8,8 \mathrm{a}$.

1919. Laccopteris? sp., Antevs, p.16, pl. 1, figs 1-3.

1926. Laccopteris groenlandica n. sp. Harris, p. 62, pl. 3, fig. 5; text-fig. 6.

1931. Laccopteris braunii Goeppert; Harris, p. 70, text-fig. 25 A.

1936. Phlebopteris muensteri Schenk; Hirmer et Hörhammer, p.17, pl. 3; pl. 4, figs1-6; text-figs 2A, 2B, 5, pictorial supplement B.

1937. Phlebopteris muensteri (Schenk) Hirmer et Hörhammer; Harris, p. 20.

1993. Phlebopteris muensteri (Schenk) Hirmer et Hörhammer; Van Konijnenburg-van Cittert, p. 240, pl. 1, figs $1,3,4 ;$ pl. 5, fig. 2 .

2009. Phlebopteris muensteri (Schenk) Hirmer et Hörhammer; Schweitzer et al., p. 33, pl. 4, figs 1-4; pl. 5, figs $1-3$; pl. 6, figs $1-3$; text figs 4 a, b.

2011. Phlebopteris muensteri (Schenk) Hirmer et Hörhammer; Pott and McLoughlin, p. 1029, figs 3 G-I, 4.

MATERIAL: One incomplete pinna fragment $7.5 \mathrm{~cm}$ long, with pinnules (mostly incomplete) preserved mainly on one side of the rachis; Muz. Geol. PIG 1794.II.2, Ciechocinek IG 1 borehole, 972.7 m, Toarcian/Aalenian boundary.

DESCRIPTION: The studied fragment of a sterile pinna has a rachis ca. $0.7 \mathrm{~mm}$ wide. The pinnules are alternate or subopposite, and the length of the longest pinnule fragment is $10 \mathrm{~mm}$. The length of the shorter pinnules, which are close to the pinna base and preserved whole, ranges from 3 to $9 \mathrm{~mm}$. The width of the pinnules is $2.5-4 \mathrm{~mm}$. The bases of adjacent pinnules are connected by a wing 1-1.2 mm wide. The apex of the pinnules narrows to subacute (P1. 3, Fig. 2). The midrib is clearly visible, and the secondary veins divide once or twice. Near the base of the pinnule, they 
tend to arise at a sharp angle, running for almost half their length nearly parallel to the midrib and then curving at almost a right angle to the pinnule margin. The remaining veins arise at an angle to the midrib of $\mathrm{ca}$. $80^{\circ}$ (Pl. 3, Fig. 3).

DISCUSSION: The studied specimen is referred to Phlebopteris muensteri and compares well with specimens known from Germany (Schenk 1867; Gothan 1914a), Greenland (Harris 1926, 1931), Poland (Raciborski 1894) and Scania (Pott and McLoughlin 2011), and discussed by Hirmer and Hörhammer (1936), as well as Schweitzer et al. (2009). P. muensteri is quite variable, in terms of pinnule shape and length (length/width ratio) or pinnule venation. In fact, this variability is, in most cases, affected by the pinna position in the leaf. The studied fragment evidently originates from the basal part of the frond, which is, however, different from the frond illustrated by Hirmer and Hörhammer (1936, pictorial supplement B), in having a non-pinnate lamina at the base. Our specimen, for the most part, resembles the fragment illustrated by Harris (1931, text fig. 25 B), referred to P. muensteri by Hirmer and Hörhammer (1936), who commented that it was a form with extremely short pinnules. In fact, the true length of the pinnules in our specimen is not fully known, because almost all the pinnules are broken.

The species has a characteristic venation, not really typical of the genus, in which the veins usually form meshes, at least at the midrib. Harris (1926, text fig. A) demonstrated such meshes on one of the pinnules from Greenland, but not as a constant feature. Generally, its venation agrees with all the material used for purposes of comparison.

The species was described from the Middle Jurassic of Grojec near Kraków by Raciborski (1894) as Laccopteris mirovensis, and revised to P. muensteri by Hirmer and Hörhammer (1936).

Family Dicksoniaceae Bower, 1908 Genus Coniopteris Brongniart, 1849

TYPE SPECIES: Coniopteris murrayana (Brongniart, 1828-1837) Brongniart, 1849 Coniopteris hymenophylloides (Brongniart, $1828-$
1837) Seward, 1900

(Pl. 3, Figs 4, 5)

1828-1838. Sphenopteris hymenophylloides $\mathrm{n}$. sp. Brongniart, p. 189 , pl. 56 , fig. 4 .
1900. Coniopteris hymenophylloides Brongniart; Seward 1900: 99, pl. 16, figs 4-6; pl. 17, fig. 7; pl. 20, figs 1, 2; pl. 21, figs 21,22 .

1913. Coniopteris hymenophylloides Brongniart; Halle, p. 19 , pl. 3, figs 23, 24, 29, 30 .

1961. Coniopteris hymenophylloides (Brongniart) Seward; Harris, p. 152, text-figs 53, 54.

1984. Coniopteris hymenophylloides (Brongniart) Seward; Bose and Banerji, p. 14, pl. 3, figs 1-5; text-figs 7 A-I.

1989. Coniopteris hymenophylloides (Brongniart) Seward; Gee, p. 159 , pl. 1, figs 7,8 .

1999. Coniopteris hymenophylloides (Brongniart) Seward; Van Konijnenburg-van Cittert and Morgans, p. 53, pl. 3, fig. 2; text-figs $23 \mathrm{~A}, \mathrm{~B}$.

2009. Coniopteris hymenophylloides (Brongniart) Harris; Schweitzer et al., p. 69, pl. 28, fig. 3; pl. 29, figs1-3; pl. 30 , figs 1,2 ; pl. 31, figs $1-4$; pl. 32, figs $1-3$; text-figs 28-31B.

2011. Coniopteris hymenophylloides (Brongniart) Harris; Bomfleur et al., p. 194, figs 5F-J.

MATERIAL: One fertile pinna fragment with pinnules, 47 mm long. KRAM-P PM: 139/106 fertile, sterile 139/104, 139/123, 73.9 m, Huta OP-1 borehole, Zagaje Formation, Huta Mudstone Member, Lower Hettangian.

DESCRIPTION: The studied fragment of the fertile frond represents the apical part of the pinna (Pl. 3, Fig. 4). Its rachis is $0.7 \mathrm{~mm}$ wide. The pinnules are almost perpendicular to the rachis and opposite, from $1.3 \mathrm{~mm}$ in length close to the apex to $3.5 \mathrm{~mm}$ at its widest point, and $1.5 \mathrm{~mm}$ close to the pinna base. Their width near the base is ca. $1.2 \mathrm{~mm}$. The pinnules are close to each other, the adjacent margins are either in touch, or the distance between them is less than $0.5 \mathrm{~mm}$. The lamina is partly reduced and divided into 4-7 opposite lobes, each one bearing a circular sorus at the end. The structure of the sori and the venation cannot be observed.

The sterile fragments are very small (Pl. 3, Fig. 5). The more complete one represents a slender rachis, 0.5 mm wide, with pinnae arising on it at angles of $80^{\circ}, 50^{\circ}$ and $45^{\circ}$ (the angle decreases towards the apex of the pinna). The rachis of the pinna is ca. $0.25 \mathrm{~mm}$. The pinnules are opposite at the base of the pinna and become katadromically alternate towards the pinna apex. Following the same path along the pinna, pinnule size ranges from $7 \times 3 \mathrm{~mm}$ to about $2 \times 2 \mathrm{~mm}$. The pinnule margins are entire to irregularly lobed or incised. The venation is slightly visible and katadromic.

DISCUSSION: The gross morphology of the fertile fragment corresponds well to the species diagnosis and illustrations given by Seward (1900). The studied pinna 
is also identical with material described from Yorkshire (Harris 1961, particularly his text fig. 54 D), which presents a fertile pinna fragment with a lamina that is not entirely reduced. The sterile pinnae, although quite poorly preserved, are attributed to the same species. Although the pinules are similar in shape to Todites princes, also present in this locality, their katadromic arrangement and venation justify this determination.

The species is typical of Middle Jurassic localities, but also occurs in the Lower Jurassic (e.g. the Mecsek Mts, Hungary). In Poland, it was reported from Grojec by Raciborski, who ascribed its several fragments to four different species (Dicksonia zarecznyi, D. heerii, Thyrsopteris murrayana, Sphenopteris sp.), which were recently revised and synonymized with Coniopteris hymenophylloides by Jarzynka (2012 unpublished thesis).

Division Pteridospermophyta Oliver and Scott, 1904 Order Peltaspermales Taylor, 1981

Family Peltaspermaceae Thomas, 1932

Genus Lepidopteris Schimper, 1869

TYPE SPECIES: Lepidopteris stuttgardiensis (Jaeger, 1827) Schimer, 1869

Lepidopteris ottonis (Goeppert, 1836) Schimper, 1869 (Pl. 3, Figs 6, 7)

1836. Alethopteris ottonis n. sp. Goeppert, p. 303, pl. 37, figs 3,4 .

1846. Pecopteris ottonis n. sp. Goeppert, p. 144, pl. 1, figs 4-10. 1867. Asplenites ottonis Goeppert; Schenk, p. 53, pl. 11.

1869. Lepidopteris ottonis Goeppert; Schimper, p. 573.

1870. Asplenites ottonis Schenk; Roemer, p. 178, pl. 13, fig. 1.

1876. Lepidoperis ottonis Goeppert; Nathorst, p. 29, pl. 1, fig. 4a; pl. 2 , fig. 1.

1914. Lepidopteris ottonis Goeppert; Antevs, p. 24, pl. 3, figs $2,2 \mathrm{a}$.

1922. Lepidopteris ottonis Goeppert; Johansson, p. 28, pl. 1, figs 1-10; pl. 6, fig. 3.

1926. Lepidopteris ottonis (Goeppert) Schimper; Harris, p. 67, text-fig. $8 \mathrm{C}, \mathrm{D}$.

1932. Lepidopteris ottonis (Goeppert) Schimper; Harris, p. 58 , pl. 5, fig. 16 ; pl. 6 , figs 2,10 ; pl. 8 , figs 8,11 , 15; textfigs $27 \mathrm{a}-\mathrm{d}$.

1950. Lepidopteris ottonis (Goeppert) Schimper; Lundblad, p. 30, pl. 4, figs 6, 7, 10; pl. 5, figs 1, 11.

1970. Lepidopteris ottonis (Goeppert) Schimper; Piwocki, p. 101, pl. 1, figs 1, 2; pl. 2, figs 3-5.

1991. Lepidopteris ottonis (Goeppert) Schimper; Barbacka, p. 25, pls. 1-5; pl. 6, figs 1-3.
MATERIAL: Three very small pinna fragments with some pinnules, about $20 \mathrm{~mm}$ long, compressed, with well preserved cuticle; Muz. Geol. PIG : 1794.II, 1794.II.5, Chabowo 2 borehole, 1220.0-1220.4 m, Rhaetian.

DESCRIPTION: The preserved pinnae fragments are part of a bipinnate leaf (Pl. 3, Fig. 6). Their rachises are c. $1 \mathrm{~mm}$ wide and the pinnules are opposite, 5-9 $\mathrm{mm}$ long and c. $3.5 \mathrm{~mm}$ wide at their bases. The pinnules arise at an angle of $60^{\circ}$ to the rachis, and are almost triangular in shape, with acute or subacute apices. The midrib is prominent, reaching the apex, and the secondary veins are invisible.

The cuticle is moderately thick. The leaf is amphistomatic; the stomata are more numerous on the lower cuticle than on the upper one. Cells on both surfaces are similar and irregularly polygonal, most of them bearing a central papilla. On the lower cuticle, the cells above the veins are more rectangular. The stomata are present in wide bands between, and occasionally above, the veins. They consist of 5-7 almost triangular subsidiary cells arranged radially, each with a prominent papilla above the stomatal pit (P1. 3, Fig. 7).

DISCUSION: The gross morphology and cuticular structure of Lepidopteris ottonis are quite distinctive and easy to recognize. In Poland, this species is common in the Rhaetian. Most of the reports are from the Kraków-Silesia Upland (Goeppert 1846; Roemer 1870; Gothan 1909), but it has also been found near Warsaw, in the Gradzanowo 3 borehole (Barbacka 1991) and the specimen studied herein is from the vicinity of Szczecin. The specimens from the Chabowo 2 borehole are typical representatives of the species. So far, $L$. ottonis has been considered a marker species for the Rhaetian. However, Marcinkiewicz and OrłowskaZwolińska (1994) reported cuticle dispersae of $L$. ottonis from the Gostyn $46 \mathrm{G}$ borehole that were dated by the pollen assemblage as Norian. Consequently, it seems that a Norian-Rhaetian range of this species could be accepted.

Family: Umkomasiaceae Petriella, 1981

Genus Pachypteris Brongniart, 1828

TYPE SPECIES: Pachypteris lanceolata Brongniart, 1828

Pachypteris sp.

(Pl. 3, Fig. 8) 
MATERIAL: Two small fragments of pinnate leaves (or pinnae), consisting of a rachis and some incomplete pinnules. Cuticle not preserved. KRAM-P PM 138/24B, 783 m, Studzianna borehole; Muz. Geol. PIG 1794.II.2, Brześć Kujawski IG 3 borehole, 2190.05 m, both Ostrowiec Formation, Lower Sinemurian.

DESCRIPTION: The larger fragment, from the Brześć Kujawski IG 3 borehole, is $6 \mathrm{~cm}$ long and represents the upper part of a small pinnate leaf. Only one of the twelve preserved pinnules is complete, in all others the apices are not preserved. The shape of the pinnules is ovate, base contracted. Two pinnules seem to be lobate at their bases. The venation is very fine and barely visible, showing an inconspicuous midrib and very thin laterals that fork once. The fragment from the Studzianna borehole represents the same type of gross morphology.

DISCUSSION: The fragment from the Studzianna borehole has been described and discussed by Barbacka and Bóka (2014). Both fragments are of the same morphological type, and probably represent the same species. Unfortunately, neither of them possesses a cuticle suitable for preparation and the fragments are too small to recognize the leaf morphology. Leaves belonging to the genus Pachypteris are known to be highly variable in pinnule shape, and can be entire, undulate or deeply lobed, even within the same leaf. For this reason, specific determination is impossible. The shape of the pinnules resembles some German samples, namely leaves belonging to Thinnfeldia: illustrated by Gothan (1914b) $T$. rhomboidalis, pl. 13, fig. 3, or T. incisa (lobed pinnules), pl. 13, fig. 2 (Gothan 1914b), as well as T. rhomboidalis, pl. 20, fig. 3, or T. belhofensis with lobed pinnules, pl. 23, fig. 5 (both Gothan 1914a) and Weber (1968, T. rhomboidalis, pl. 8, fig. 83, pl. 10, fig. 100). However, in the Polish samples, the pinnule bases are even more contracted than in the other illustrated specimens.

Division Ginkgophyta Bessey, 1907

Order Ginkgoales Gorozhankin, 1904

Genus Ginkgoites Seward, 1919

TYPE SPECIES: Ginkgoites obovata (Nathorst, 1886) Seward, 1919

Ginkgoites ef. marginatus (Nathorst, 1878) Florin, 1936 (Pl. 4, Figs 1-4)

1878. Baiera marginata n. sp. Nathorst, p. 51, pl. 8, figs $12-$ 14.
1935. Ginkgoites hermelini Hartz; Harris, p.13, pl. 1, figs 8-10; pl. 2, figs 5, 6; text-figs 6-8.

1936. Ginkgoites marginatus Nathorst; Florin, 107.

1937. Ginkgoites hermelini (Hartz) Harris; Harris, p. 57.

1959. Ginkgoites marginatus (Nathorst) Florin; Lundblad, p. 10 , pls 1,2 , text-figs $1-4$.

1961. Ginkgoites marginatus (Nathorst) Florin; Nagy, p. 629, pls. $16,17$.

1961. ?Arctobaiera sp., Nagy, p. 630, pl. 15, fig. 2.

2002. Ginkgoites marginatus (Nathorst) Florin; Barbacka, p. 698, pl. 1, figs 1-8.

MATERIAL: Small fragment of ginkgolean leaf, 14-33 mm long, with cuticle suitable for preparation; 138/48 II, 980 m, Studzianna borehole, Zagaje Formation (Lower Hettangian).

DESCRIPTION: The specimen is preserved as a leaf fragment, with four segments probably comprising a whole leaf, without base and with broken apices (P1. 4, Fig. 4). One of the segments is twice dichotomized. The segments are 3-8 mm wide at the widest preserved points. Veins are weakly recognizable, about 10 per segment.

The leaf is amphistomatic. The upper cuticle is a little thicker than the lower. The shape of epidermal cells on both the upper and lower cuticles ranges from rectangular or almost square to irregular (Pl. 4, Figs 1, 2). Over the veins, they tend to be rectangular. A central papilla is visible on numerous cells, especially between the veins. The stomata, in almost equal numbers on both cuticles, are arranged between the veins, sometimes forming short rows. They consist of 4-6 (but mostly 4) subsidiary cells with prominent papillae. Oval resin bodies are present (Pl. 4, Fig. 3).

DISCUSSION: Ginkgoites marginatus is mainly known from the Liassic of Sweden, Greenland (originally G. hermelini) and Hungary. Our specimen has unfortunately an unrecognizable leaf shape, since only some of the lobes were preserved. Ginkgoites, Baiera and Sphenobaiera may have similar shape of leaf segments, however, in our material the number of veins in one segment is 10 , whereas in Baiera, there are typically no more than 4 (see also discussion; Barbacka 2002). In Sphenobaiera, the number of veins per segment can be about 10 (11 in $S$. ophioglossum; Harris and Millington 1974), but the cuticle of this species does not correspond to the cuticle in our specimen. In fact, the studied specimen has a cuticle very similar to that of $G$. marginatus from Hungary, only the papillae are more frequent in the Polish sample. This is probably caused by environmental differences. Still, the specimen from Poland in gross morphology and cuticle 
structure corresponds very well to those described and widely discussed by Lundblad (1959).

\section{Ginkgoites sp. \\ (P1. 4, Figs 5, 6)}

MATERIAL: Single specimen; KRAM-P PM: 138/39A, 138/ 84A (part and counterpart), $862 \mathrm{~m}$, Studzianna borehole, Przysucha Ore Bearing Formation, Hettangian.

DESCRIPTION: The specimen is represented by a leaf fragment with 3 segments, without a base and apex (Pl. 4 , Figs 5,6 ). One of the segments is forked once. The length of segments is $10-15 \mathrm{~mm}$, strongly narrowing towards the leaf base. The width of segments at the widest point is $4.5 \mathrm{~mm}$; at the narrowest point near the base, is $2 \mathrm{~mm}$. Veins are well marked, single or forked; at the widest point, 5-6 veins are observable.

Due to the cuticle's state, it was only possible to obtain a very small piece. No stomata are visible on this fragment. The cuticle, probably the upper, is thick, and cells are irregular without papillae or hair bases. Cell walls are straight (Pl. 4, Fig. 6). No other structures are visible.

DISCUSSION: Due to its small size and unrecognizable cuticle, the specimen cannot be attributed to a species. It is worth mentioning, because this is the only Ginkgo-like remnant from the source locality. We recognized the remnant as Ginkgoites sp. based on its morphological features, which differentiate it as Ginkgoites as opposed to Baiera, as discussed by Harris and Millington (1974). Although the authors proposed using the generic name Ginkgo instead of Ginkgoites for Mesozoic foliages as well, we think that Ginkgoites is a convenient name for those leaves which are not associated with reproductive organs of the Ginkgo type (see also Barbacka 2002).

Genus Baiera Braun, 1843, emend. Florin, 1936

TYPE SPECIES: Baiera dichotoma Braun, 1843

Baiera furcata (Lindley and Hutton, 1837) Braun, 1843

(Pl. 4, Figs 7, 8; Pl. 5, Figs 1-3)

1837. Solenites? furcata n. sp. Lindley and Hutton, p. 209. 1843. Baiera furcata Lindley and Hutton; Braun, p. 21.

?1971. Ginkgoites baieraeformis n. sp. Kilpper, p. 92, pl. 25, figs 3; pl. 28, figs 4; text-fig. 3.
?1971. cf. Ginkgoites baieraeformis Kilpper, p. 93, pl. 25, figs 5; pl. 29, fig. 1; text-fig. 4.

1974. Baiera furcata (Lindley and Hutton) Braun; Harris and Millington, p. 30 with synonyms, pl. 1, figs 1, 2; textfigs $10-13$.

?1995. Baiera baieraeformis Kilpper; Schweitzer and Kirchner, p. 24, pl. 6, figs 1-5, text-figs $13 \mathrm{a}-\mathrm{g}$.

1995. Baiera furcata (Lindley and Hutton) Braun; Schweitzer and Kirchner, p. 26, pl. 7, figs 1-9; text-figs 14 a-d, 15.

2002. Baiera furcata (Lindley and Hutton) Braun; Barbacka, p. 703, pl. 3, figs $1-8$, pl. 4, figs $1-5$; text-figs 3 A-J.

MATERIAL: One incomplete specimen with eight segments visible, apices of segments not preserved; KRAM-P PM 139/4+269 (part and counterpart), Huta OP-1 borehole, 71.2 m, Zagaje Formation, Huta Mudstone Member, Lower Hettangian.

DESCRIPTION: The leaf is petiolate, the blade is deeply dissected, and each half is dissected again into segments (Pl. 4, Fig. 7). The segments in the widest preserved part are $3-3.5 \mathrm{~mm}$ wide. The number of veins is not clear, but it is noticeable that the distance between veins is quite large, about $0.8 \mathrm{~mm}$, so their number may be estimated as about four per segment.

The leaf is amphistomatic with an almost equal number of stomata on the thicker (upper) and thinner (lower) cuticle. On the thicker cuticle, the veins are more strongly marked by very elongated cells with thick cell walls, while between the veins, the cells are irregular and sometimes have undulated walls (Pl. 5, Fig. 1). The stomata are distributed between the veins, irregularly or forming short files. They consist of 5-6 rather large and irregular subsidiary cells; sometimes encircling cells are found. There is thickening around the stomatal pit, which tends to turn into papillae (P1. 5, Figs 2, 3). On the thinner cuticle, the veins are indicated by less elongated, rather rectangular cells, and the cells between the veins are a little larger than on the thicker cuticle (Pl. 4, Fig. 8). Stomata distribution and morphology is the same as on the thicker cuticle.

DISCUSSION: The leaf blade shape, number of veins and size of the preserved parts of the segments, as well as the structure of the cuticle best correspond to Baiera furcata (Lindley and Hutton) Braun (Harris and Millington 1974; Schweitzer and Kirchner 1995; Barbacka 2002) and B. muensteriana (Presl in Sternberg) Heer (Heer 1876; Gothan 1914a; Weber 1968; Kirchner 1992; Schweitzer and Kirchner 1995). As emphasized by Seward (1919), both species are very similar to each other. $B$. muensteriana is mainly known from the German Rhaetian-Jurassic, while B. furcata (united with $B$. gra- 
cilis and B. scalbiensis by Harris and Millington 1974) has been reported from the Middle Jurrasic of Yorkshire and the Liassic of Hungary (Barbacka 2002). The studied leaf has a very similar structure (including its cuticle) to specimens from Iran described as Ginkgoites baieraeformis (Kilpper 1971) and renamed as Baiera baieraeformis by Schweitzer and Kirchner (1995), which were included among synonyms of $B$. furcata (Barbacka 2002). It has not been ruled out that all the above forms represent one species and should be united under the name Baiera furcata.

\section{cf. Baiera sp.}

(P1. 5, Figs 4-8; P1. 6, Fig. 1)

MATERIAL: Two leaf fragments without a base or segmental apices, with a cuticle suitable for preparation; KRAM-P PM 139/296, 139/301 Huta OP-1 borehole, $72.9 \mathrm{~m}$, Zagaje Formation, Huta Mudstone Member, Lower Hettangian.

DESCRIPTION: Separate segments belonging to two leaves are 4-7 mm wide in the widest part of the preserved fragments (Pl. 5, Fig. 4). The number of veins in narrower segments is 4 ?, and 7 ? (probably above the forking) in the widest segment. The leaf is amphistomatic. Stomata are present in equal number on both lower and upper cuticles. On the upper cuticle, the veins are clearly indicated by rectangular, elongated cells; the cells between the veins are irregular (P1. 5, Fig. 8). The cell walls are straight or slightly undulate. On the lower cuticle, the cells above the veins are rectangular, but not as elongated as on the upper cuticle (P1. 5, Fig. 6). Stomata occur between the veins in wide bands, irregularly distributed, occasionally present on the veins as well. The stomatal apparatus consists of 5-6 small subsidiary cells and guard cells equally thickened across their whole surface (P1. 5, Fig. 7; P1. 6, Fig. 1). The stomatal pore is small (about $6 \mu \mathrm{m}$ ). The subsidiary cells extend only a little beyond the guard cells, which are about $40 \mu \mathrm{m}$ wide and together with each other; a frequently incomplete or complete ring of encircling cells is observable. Circular or oval resin bodies, $200-300 \mu \mathrm{m}$ in length, occur between the lower and upper cuticles (Pl. 5, Fig. 5).

DISCUSSION: Since the leaf bases and segmental apices in studied specimens are lacking, it is very difficult to define to which genus the specimens should be referred. Its assignation to Baiera is based on 4 ? veins in the segments (distances between the veins suggest such a number), while in typical Ginkgoites, the number of veins is more than that, and often up to 10 (Harris and
Millington 1974). The most important feature differentiating Ginkgoites, Baiera and Sphenobaiera is the shape of the leaf base, or the presence of one vein at the leaf base in Sphenobaiera, and two in Ginkgoites. The latter feature is often difficult to observe due to the poor state of preservation, or useless in the case of separate segments.

Based on cuticle structure, our specimens should be attributed to Sphenobaiera, considering that the stomata occur in wide bands between the veins, or on the actual veins too. This feature is often observed in Sphenobaiera (Harris and Millington 1974), however, gross morphology and cuticular structure in Ginkgoales are very variable.

Family Pseudotorelliaceae Krassilov, 1972 Genus Pseudotorellia Florin, 1936

TYPE SPECIES: Pseudotorellia nordenskioeldii (Nathorst, 1897) Florin, 1936

\author{
Pseudotorellia nordenskioeldii (Nathorst, 1897) \\ Florin, 1936 \\ (Pl. 6, Figs 2-7)
}

1936. Pseudotorellia nordenskioeldii Nathorst; Florin, p. 139 , pl. 38, figs 2-5, text-fig. 17.

MATERIAL: Four fragments belonging to several separate leaves without bases or apices but with a cuticle suitable for preparation; KRAM-P PM 138/88, 1010.81015.8, Studzianna 1 borehole, Zagaje Formation, Lower Hettangian, 138/24, 138/25/II, 138/28/II, 783 m, Ostrowiec Formation, Lower Sinemurian.

DESCRIPTION: The best preserved and most representative specimen is a fragment without base and apex, $55 \mathrm{~mm}$ long and $3.5 \mathrm{~mm}$ wide at its widest point ( $\mathrm{Pl}$. 6, Figs 2,3). The width of the other samples reaches 4-4.5 $\mathrm{mm}$. Both ends of the remnant are narrow; the widest point is at the middle of the leaf. The veins are parallel, and about 8 in number, but only a small section is visible.

The leaf is hypostomatic. The cuticle is moderately thick, and its upper and lower surfaces are of equal thickness. On both cuticles, the veins are marked by elongated cells that have a length/width ratio of 5:1-11:1. The other cells have a ratio of $2: 1-6: 1$. Epidermal cells are rectangular in shape, but their corners are rounded. The cell walls are straight, sometimes undulate (Pl. 6, Figs 4-7). 
The stomata are restricted to the bands between the veins. They are oriented longitudinally and distributed rather sparsely in more or less regular files, about 3 files per band (Pl. 6, Figs 4, 5, 7). The subsidiary cells, 5-6 in number, are large and rather irregular; in most cases, the polar cells are recognisable, but sometimes the subsidiary cells are distributed irregularly. Guard cells are thickened; papillae are not found around the stomatal pit or on the other cells.

DISCUSSION: Pseudotorellia nordenskioeldii was described by Nathorst (originally Feildenia nordenskioeldii, then Torellia nordenskioeldii) from the Wealden of Advent Bay, Spitzbergen. Orlovskaja (1962) described this species from the Jurassic of Kazakhstan, but according to Lunblad (1968) the differences from the original material are quite significant both in terms of gross morphology and cuticlar structure.

Several species of Pseudotorellia are known from the Jurassic and Cretaceous: Greenland (Harris 1935), Scania (Lundblad 1957), Poland (Reymanówna 1963; Wcisło-Luraniec 1989), Yorkshire (Harris and Millington 1974), the former USSR (Doludenko 1961; Orlovskaja 1962; Gomolitzky 1965; Doludenko and Samylina 1992), Spitzbergen (Bose and Manum 1990), Iran (Schweitzer and Kirchner 1995), Siberia (Kostina 2004) and the Middle Caspian Basin (Kiritchkova and Nosova 2012). For a full review of the genus see Kiritchkova and Nosova (2009). Many species have only been reported once, but $P$. longifolia Doludenko has been reported more frequently.

The studied specimens corresponds best to $P$. nordenskioeldii. Other similar species (possessing a similar cellular pattern and no papillae on the subsidiary cells) are $P$. longifolia Doludenko and $P$. angustifolia Doludenko. The former differs, however, in stomatal distribution (irregular in P. longifolia) and in very weakly marked veins on the cuticle; cf. Doludenko 1961; Kostina 2004), and the latter is consistently very narrow (2.5-3 $\mathrm{mm})$ and possesses no more than 4 veins.

Pseudotorellia sp. (P1. 6, Fig. 8; Pl. 7, Fig. 1)

MATERIAL: One complete leaf; cuticle unsuitable for preparation; KRAM-P PM: 139/158-159 (part and counterpart), Huta OP-1 borehole 76.4 m, all Zagaje Formation, Lower Hettangian.

DESCRIPTION: The detached leaf is $35 \mathrm{~mm}$ long and $5 \mathrm{~mm}$ wide in the middle (its widest part). Its margins run parallel to each other for a short distance (Pl. 6, Fig. 8).
The apex narrows gradually and is obtuse. The base narrows more rapidly, but forms an elongated end (not really a petiole, Pl. 7, Fig. 1). At the base, the veins, probably two, dichotomize to reach 12 veins in the first third of the leaf.

DISCUSSION: The leaf gross morphology corresponds well to the diagnosis of the genus (Florin 1936; translated by Lunblad 1957). The genus was also discussed by Harris and Millington (1974). Our specimen is not determinable to a species level because it lacks a good cuticle, but its morphology is close to $P$. grojecensis Reymanówna (1963).

Order Leptostrobales Meyen, 1987

Family Leptostrobaceae Meyen, 1987

Genus Czekanowskia Heer, 1876

TYPE SPECIES: Czekanowskia setacea Heer, 1876

Czekanowskia hartzi Harris, 1926

(P1. 7, Figs 2-5)

1926 Czekanowskia hartzi n. sp. Harris, p. 104, pl. 4, figs $1-3$; text-figs $25 \mathrm{E}-\mathrm{G}$.

1935 Czekanowskia hartzi Harris; Harris, p. 38, pl. 4, figs 4, 5; pl. 6, figs 1, 9-11.

MATERIAL: KRAM-P PM: 138/7, 138/8A, 138/9, 138/83A, 138/84, 138/85, 862 m, Przysucha Ore Bearing Formation, Upper Hettangian; 138/49, 138/51, 1013 $\mathrm{m}$, Zagaje Formation, Lower Hettangian, Studzianna borehole

DESCRIPTION: Fragmented leaf; separated segments are mainly preserved in crowded groups of 7-8 to more than 20 broken fragments without base or apex (Pl. 7, Fig. 2). They are simple or once dichotomically forked, from $3 \mathrm{~mm}$ to $100 \mathrm{~mm}$ long and $0.75-1.0 \mathrm{~mm}$ wide below the dichotomy. Veins (1-2) run parallel along the whole length of the blade.

The leaf is amphistomatic. The cuticle is rather thin, and the upper and lower cuticles are of almost equal thickness (P1. 7, Figs 3-5). The cell pattern is also similar on both cuticles. The stomata form 4 longitudinal files alternating with rows of elongated cells (Pl. 7, Fig. 3). The size of the elongated cells between the stomatal rows and at the segment margin is about $80-10 \mu \mathrm{m} \times 10-15$ $\mu \mathrm{m}$, while in the stomatal files, the cells are rectangular to irregular, about $40-70 \mu \mathrm{m} \times 20-30 \mu \mathrm{m}$. The stomatal files are separated from each other by $4-8$ rows of elon- 
gated cells. The stomata are haplocheilic, longitudinally oriented and about $60-90 \mu \mathrm{m}$ long. The guard cells are weakly cutinised with slightly thickened poral walls (P1. 7 , Figs 4,5 ). The aperture is elongated, about $12-25 \mu \mathrm{m}$ long. Besides the subsidiary cells at the poles, there are 1-2 subsidiary cells on each side. On the lower cuticle, some of the lateral subsidiary cells tend to form papillae, which is not observable on the upper cuticle.

DISCUSSION: The specimens are ascribed to the species $C$. hartzii. However, its entire gross morphology, in particular the base, is not observable. It is not possible to note the number of segments within the leaf, which is one of the diagnostic features. Nevertheless, the appearance and size of the segments as well as the cuticular structure correspond to C. hartzii. In fact, species of Czekanowskia are hardly distinguishable from each other, since they have weakly differentiated cuticles. C. hartzii resembles C. blackii to such a high degree that they might be conspecific. Harris and Miller (1974) proposed, however, the separation of these species according to the ages in which they occurred - the Early and Middle Jurassic respectively. Our specimens differ slightly from Harris' material in having papillae on some of the subsidiary cells on the lower cuticle. The presence of such irregular papillae can be interpreted as being caused by environmental circumstances.

Many species of Czekanowskia have been described on the basis of macro- and micromorphology. The former USSR was especially rich in Czekanowskia species (Samylina and Kiritchkova 1991). In Europe, different species of Czekanowskia have been reported, mainly from Greenland and Yorkshire (Harris 1926, 1935; Harris and Miller 1974), Sweden (Nathorst 1906; Johannson 1922) and Poland (Gromadzice, Chmielów, Podszkodzie - Raciborski 1892; Makarewiczówna 1928).

\section{Czekanowskia rigida Heer, 1876}

(P1. 7, Figs 6-8; Pl. 8, Fig. 1)

1929. Czekanowskia rigida Heer; Black, p. 429, text-fig. 16.

1936. Czekanowskia rigida Heer; Florin, p. 131, pl. 32, fig. 10; pl. 33, figs 1,2 .

1991. Czekanowskia rigida Heer; Samylina and Kiritchkova, p. 65, pl. 1, fig. 6; pl. 6, fig. 1; pl. 41; text-fig. 34 .

MATERIAL: KRAM-P PM: 138/ 8A, B, 862 m, Przysucha Ore-bearing Formation, Upper Hettangian, 138/39 B, C, 138/42, 138/43, 980 m, Zagaje Formation, Lower Hettangian, Studzianna borehole.
DESCRIPTION: No complete leaf was found. Separate segments are mainly preserved in crowded groups of three to several broken fragments without base or apex. They are simple or once dichotomically forked, from 30 $\mathrm{mm}$ to $100 \mathrm{~mm}$ long and $1 \mathrm{~mm}$ wide below the dichotomy (P1. 7, Fig. 6). Above the dichotomy, they become slightly narrower, reaching about $0.8 \mathrm{~mm}$ in width. Veins run parallel along the whole length of the blade, up to three, if visible.

The leaf is amphistomatic. The upper cuticle is noticeably thicker than the lower. Cell patterns are similar on both cuticles. The stomata are arranged in 6-8 longitudinal files (P1. 7, Fig. 7), alternated with files of very long and narrow cells $(100-125 \times 10-15 \mu \mathrm{m})$. In the stomatal rows, cells are more rectangular or irregular in shape $(30-45 \times 15-20 \mu \mathrm{m})$. Groups of subsidiary cells are irregular and thicker than ordinary cells. Besides pole-cells, there are 1-2 lateral subsidiary cells, but thickened groups consist of 6-8 cells. The subsidiary cells sometimes possess flat papillae over the stomatal pit. The stomata length ranges between 70 and $100 \mu \mathrm{m}$ (Pl. 7, Fig. 8; Pl. 8, Fig. 1).

DISCUSSION: Although only separated segments were found, it was not possible to observe the number of segments per leaf. Their size, especially the difference in width below and above the dichotomy, as well as the characteristically thickened stomata, made it possible, however, to identify the specimens as belonging to the widespread species, $C$. rigida. Our specimens do not possess papillae as prominent as those illustrated by Samylina and Kiritchkova (1991), but other authors, like Florin (1936) or Black (1929), did not report papillae within the stomata.

Our specimen corresponds well to the material of Czekanowskia rigida from Scania, housed in the W. Szafer Institute of Botany Polish Academy of Sciences, Kraków (No 42/19), as far as cuticular structure is concerned.

This species is known from localities (Gromadzice, Chmielów) close to location of the source Studzianna borehole.

Genus Phoenicopsis Heer, 1876

TYPE SPECIES: Phoenicopsis angustifolia Heer, 1876

Phoenicopsis insolita Nosova et Kiritchkova, 2011 (Pl. 8, Figs 2-6)

2011. Phoenicopsis insolita n. sp. Nosova and Kiritchkova, p. 116 , pls 1,2 . 
MATERIAL: Three leaf fragments without base or apex, with preserved cuticle. Hand specimens: KRAMP PM: 138/47/I, 980 m, 138/70/I, 1014 m, Zagaje Formation, Lower Hettangian , 138/87, 768-771 m, Ostrowiec Formation, Lower Sinemurian, Studzianna borehole.

DESCRIPTION: The preserved leaf fragments represent the middle parts of the leaves. The length of fragments is $26-36 \mathrm{~mm}$, and their width, $3-6 \mathrm{~mm}$. The fragments are linear with entire margins and 6-10 parallel veins in different specimens (P1. 8, Fig. 2).

The leaves are hypostomatic, but on the upper cuticle stomata occur only occasionally. The upper and lower cuticles are of almost the same thickness. On the upper cuticle, cells are irregular and uniform; veins are not indicated (P1. 8, Fig. 5). The cell walls are straight, and their corners sharp. On the lower cuticle, veins are indicated by rectangular cells. Between the veins, the cells are irregular and sometimes possess a central papilla (P1. 8, Figs 3, 4). The stomata occur in wide bands between the veins, where they are scattered and irregularly oriented. 4-6 subsidiary cells bear large papillae directed towards the stomatal pore (Pl. 8, Fig. 6).

DISCUSSION: Phoenicopsis is one of the genera representing elongated leaves with parallel margins and venation, but seems to be quite heterogenic. In fact, there are not so many species with well-preserved cuticles; many taxa are based on gross morphology alone. Since only fragments of leaves were usually found, their full shape and size are unknown. The species was established for material from Western Kazakhstan, and was described from the Toarcian (Nosova and Kiritchkova 2011). The authors proposed new species on the grounds of macro-morphology and the cuticular structure of the leaves they examined, and discussed them in comparison with other, already familiar, taxa. Our material corresponds in all features to the diagnosis of this species, as well as with the published illustrations, so, although only small fragments were found, they have been attributed to $P$. insolita.

Genus Ixostrobus Raciborski, 1892

TYPE SPECIES: Ixostrobus siemiradzkii (Raciborski, 1891) Raciborski, 1892

Ixostrobus groenlandicus Harris, 1935 (Pl. 8, Figs 7, 8)
1935. Ixostrobus groenlandicus n. sp. Harris, p. 147, pl. 27, figs 12, 13, pl. 28, figs $1-4,7-10,12$; text-fig. $50 \mathrm{G}$.

2000. Ixostrobus grenlandicus Harris; Wcisło-Luraniec and Barbacka, p. 36, fig. 2.

MATERIAL: KRAM-P PM 139/14+15 (part and counterpart), $70.5 \mathrm{~m}$; 139/16, $64 \mathrm{~m}, 139 / 270+275$ (part and counterpart) 72.2-73.4 m. All Huta OP-1 borehole, Zagaje Formation, Hettangian, Lower Jurassic.

DESCRIPTION: The material is represented by fragments of male cones. The cone is elongated, slightly narrowing towards the apex, and consists of dense microsporophylls, decurrently and helically arranged on the axis (Pl. 8, Figs 7, 8). The cones are incomplete; the largest fragment is $45 \mathrm{~mm}$ in length, and $12 \mathrm{~mm}$ in width. The width of the axis is $1-2 \mathrm{~mm}$. The microsporophylls are 5-7 mm long and $0.5 \mathrm{~mm}$ wide, arising at an angle of $45^{\circ}$ to the axis in the upper part of the cone, and $80^{\circ}$ at the base of the cone. The distal ends of the microsporophylls divide into 3 lobes, in most cases poorly preserved (P1. 8, Fig. 8).

DISCUSSION: The genus Ixostrobus was created by Raciborski (1892) based on specimens from the Liassic of the Holy Cross Mountains, Poland. According to Raciborski, the genus represented gymnospermal male cones with a relatively loose arrangement of microsporophylls and one microsporangium on their distal end. Raciborski's original Ixostrobus specimens are poorly preserved and in need of revision (Pacyna and Zdebska 2011). We think that his material is heterogenic, and could be referred to two species: the more robust specimens are typical Ixostrobus (Taxites) siemiradzkii (Raciborski 1891), while the specimens described later are more slender (Raciborski 1892). Makarewiczówna (1928) reported numerous specimens collected in the Holy Cross Mountains (Chmielów and Podszkodzie, Upper Liassic) determined as I. siemiradzkii. She placed the species I. siemiradzkii into the genus Stenorachis but without clear reason, referring only to similar material from the Rhaetian-Liassic of Scania and the Jurassic of Siberia. She did not illustrate her material and it was recently discovered that it has been lost.

Harris (1935) described the species Ixostrobus groenlandicus from the Liassic of Scoresby Sound and corrected the generic diagnosis, which was again changed by Harris and Miller (1974). They also discussed the genus Ixostrobus in depth. Wcisło-Luraniec and Barbacka (2000) described I. groenlandicus from the Hungarian Liassic and revised the Raciborski type material which was used as a basis for creating the genus. From 
North Iran, Schweitzer and Kirchner (1995) reported on Ixostrobus longicalcaratus, which differs from other species in having four free microsporangia on the microsporophyll.

Harris and Miller (1974) pointed out that male cones from different species of Ixostrobus have a very similar morphology and differ mostly in terms of the number and size of microsporangia, number and density of microsporophylls and proportion between microsporophylls and axes. The most difficult parameter to define is the number of microsporagia per sporophyll, since they are usually very poorly preserved and barely visible. Raciborski (1892) observed only one and Harris (1935) mentioned two, while Krassilov (1972) reported four microsporangia per microsporophyll. Our specimens were assigned to I. groenlandicus on the basis of their slender morphology, the angle of microsporophylls on the axis and the structure of the distal part of the sporophylls, although these are only poorly visible. Generally, they are very similar to those illustrated by Harris (1935). The distal ends are divided into three lobes, but in most cases they are incomplete ( $\mathrm{Pl}$. 8, figs 7, 8). At the distal ends of some microsporophylls, spherical structures (microsporangia?) are visible, but their organic connection with the microsporophylls is poorly visible. The slender cone structure and their size, differentiate our specimens from Raciborski's type material (1891).

According to many authors, Lxostrobus is often associated with the leaves of Czekanowskia (Raciborski 1892; Harris 1935; Harris and Miller 1974; Krassilov 1970, 1972; Taylor et al. 2009) and is attributed to the order Czekanowskiales (=Leptostrobales). Harris and Miller (1974) discussed the co-occurrence of Ixostrobus with leaves belonging to Czekanowskia, Desmiophyllum and Podozamites. In the Huta OP-1 borehole numerous leaves and shoots belonging to all three genera are found.

Division Pinophyta Cronquist, Takhtajan and Zimmermann, 1966

Order Pinales Dumortier, 1829

Genus Podozamites Braun, 1843

TYPE SPECIES: Podozamites distans (Presl in Sternberg, 1838) Braun in Münster, 1843

Podozamites distans (Presl in Sternberg 1838) Braun in Münster 1843

(P1. 9, Figs 1, 2)
1926. Podozamites distans (Presl) Braun; Harris, p. 110, textfigs $27 \mathrm{~A}-\mathrm{D}$.

1935. Podozamites distans (Presl) Braun; Harris, p. 94, pl. 16, figs 3, 6; text-figs $37 \mathrm{~A}, \mathrm{H}$.

1935. Podozamites sp. B cf. P. distans Harris, p. 95.

MATERIAL: Fragments of leafy shoots and several specimens with separate leaves; the cuticle not suitable for preparation; Large form, KRAM-P PM: 139/70/

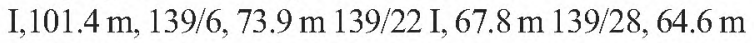
$139 / 41,65.5 \mathrm{~m}, 139 / 82,73.0 \mathrm{~m}, 139 / 13576.4 \mathrm{~m}$,

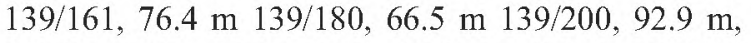
139/298-302, $73.2 \mathrm{~m}$; Small form, KRAM-P PM:

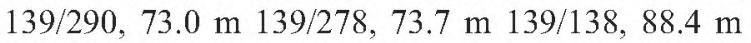
139/92 $70.8 \mathrm{~m}$, all Zagaje Formation, Huta Mudstone Member, Lower Hettangian, Huta OP-1 borehole.

DESCRIPTION: Two morphotypes of shoots are present in the material: the larger and smaller form (P1. 9, Figs 1,2 ). Both forms have rather slender axes, 0.5-1 mm wide, slightly striated longitudinally. The leaves are arranged distichously and alternately. In the larger form, they are all incomplete. The largest leaf fragment, which is almost complete, reaches $41 \mathrm{~mm}$ in length and is 7.5 mm wide, while in the smaller form, the largest complete leaf is $31.5 \mathrm{~mm}$ long and $3.8 \mathrm{~mm}$ wide. The leaf margins are slightly curved and the maximum width is at the middle of the blade. Apices are subacute, bases contracted. The veins, which are thin and inconspicuous (10-14 in the large form and 8-10 in the small form), run in parallel and converge at the apex.

DISCUSSION: The genus Podozamites contains species divided by Harris (1935) into two main groups depending on whether their leaves are attached spirally or distichously. In fossil material, it is often difficult to recognize the type of attachment, due to possible dislocation of leaves during transport and burial. Despite this, it seems that our specimens belong to the group with distichously attached leaves, and their morphology corresponds to Podozamites distans, as described by (Harris $1926,1935)$ from Greenland. It seems possible that both forms represent the same species in accordance with the usual variability occurring within any species.

Genus Brachyphyllum Brongniart, 1828

TYPE SPECIES: Brachyphyllum mamillare Brongniart, 1828

Brachyphyllum sp.

(P1. 9, Figs 3-5) 
MATERIAL: One small fragment of shoot with leaves; cuticle poorly preserved, but suitable for preparation; KRAM-P PM 139/206, 137.1 m, Huta OP-1 borehole, Zagaje Formation, Hettangian, Lower Jurassic.

DESCRIPTION: The shoot is covered by spirally arranged leaves $1.5 \mathrm{~mm}$ wide and ca. $2 \mathrm{~mm}$ long with a cushion (P1. 9, Fig. 3). The leaves are rhomboidal, and their free part is about $0.5 \mathrm{~mm}$. The apex of the preserved leaves is subacute. The cuticle is thick, but damaged. Epidermal cells are irregular with thick straight cell walls. The stomata arrangement is barely observable, because of the small size of the fragments of prepared cuticle. Their orientation is irregular (Pl. 9, Fig. 4). It seems that on the upper cuticle, the stomata are less frequent than on the lower one. Each stoma consists of ca. 6 subsidiary cells surrounding guard cells (here not preserved). Papillae are lacking on the entire cuticle (P1. 9, Fig. 5).

DISCUSSION: The preserved fragment is small and poorly preserved. Many diagnostic features are not present. The gross morphology complies with the generic diagnosis, but specific determination is impossible.

Genus Desmiophyllum Lesquereux, 1878 emend. Miller and Hickey, 2010

TYPE SPECIES: Desmiophyllum gracile Lesquereux, 1878

Desmiophyllum harrisii Barbacka et Pacyna sp. nov. (Text-figs 3, 4; Pl. 9, Figs 6-8)

1935. Desmiophyllum type 2, Harris, p. 98, pl. 17, fig. 15.

ETYMOLOGY: The species is named in honor of T.M Harris, who first described this form from Greenland.

HOLOTYPE: KRAM-P PM 139/110, Text-figs 3, 4; Pl. 9, Figs 6-8.

TYPE LOCALITY: Huta OP-1 borehole, northern margin of the Holy Cross Mountains

STRATIGRAPHIC HORIZON: $67.8 \mathrm{~m}$, Zagaje Formation, Huta Mudstone Member, Lower Hettangian

MATERIAL: Two fragments of leaf with length restricted by the edge of the core; cuticle barely preparable.
HAND SPECIMEN: KRAM-P PM 139/39, 67 m, Huta OP-1 borehole, Zagaje Formation, Huta Mudstone Member, Lower Hettangian.

REPOSITORY: The palaeobotanical collection of the W. Szafer Institute of Botany, Polish Academy of Sciences, Kraków.

DIAGNOSIS: Leaf over $27 \mathrm{~cm}$ long, 2-6 mm wide, linear. Veins parallel, 3-8 in number. Leaf probably hypostomatic, cells uniform on both lower and upper cuticle, very long, cell walls straight, longitudinally parallel. Stomata rare and large, guard cells with extended pole ends, subsidiary cells not specialized.

DESCRIPTION: The leaves were found detached. Their length in the material described here does not exceed $110 \mathrm{~mm}$, as it was limited by the core diameter. Their width is $4 \mathrm{~mm}$. The preserved fragments are linear, with parallel margins and without an apex or base (P1. 9, Fig. 6). The veins are well marked, straight, parallel, five along the width of the leaf(P1. 9, Fig. 7). The cuticle is barely preparable and very thin; only small fragments were obtained after maceration. The leaf seems to be hypostomatic. Both cuticles, lower and upper, are of equal thickness. Cells are similar on both cuticles, very long with parallel longitudinal walls (P1. 9, Fig. 8; Text-fig. 4.1). Their length exceeds 160 $\mu \mathrm{m}$, and they are from 5 to $20 \mu \mathrm{m}$ in width. Where visible, the transversal cell walls are oblique. Stomata are sparsely distributed and orientated longitudinally (Text-fig. 4.2, 4.3). They consist of 4 to 5 subsidiary cells: usually two raised subsidiary cells on the sides of the stomatal pit, and two elongated polar cells. The side cells are 50-65 $\mu \mathrm{m}$ long and $18-20 \mu \mathrm{m}$ wide. They have extended ends and thickened poral walls. The guard cells are not visible, so were probably destroyed during preparation.

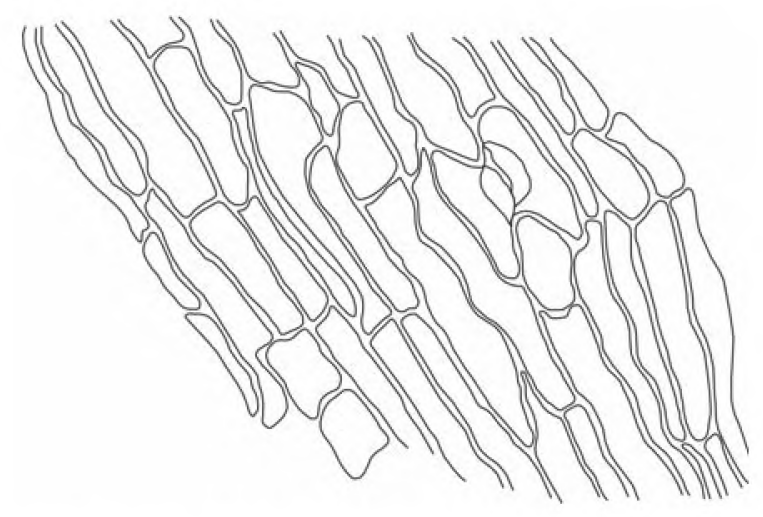

Text-fig. 3. Desmiophylum harrisit sp. nov., schematic drawing of the lower cuticle with stoma 

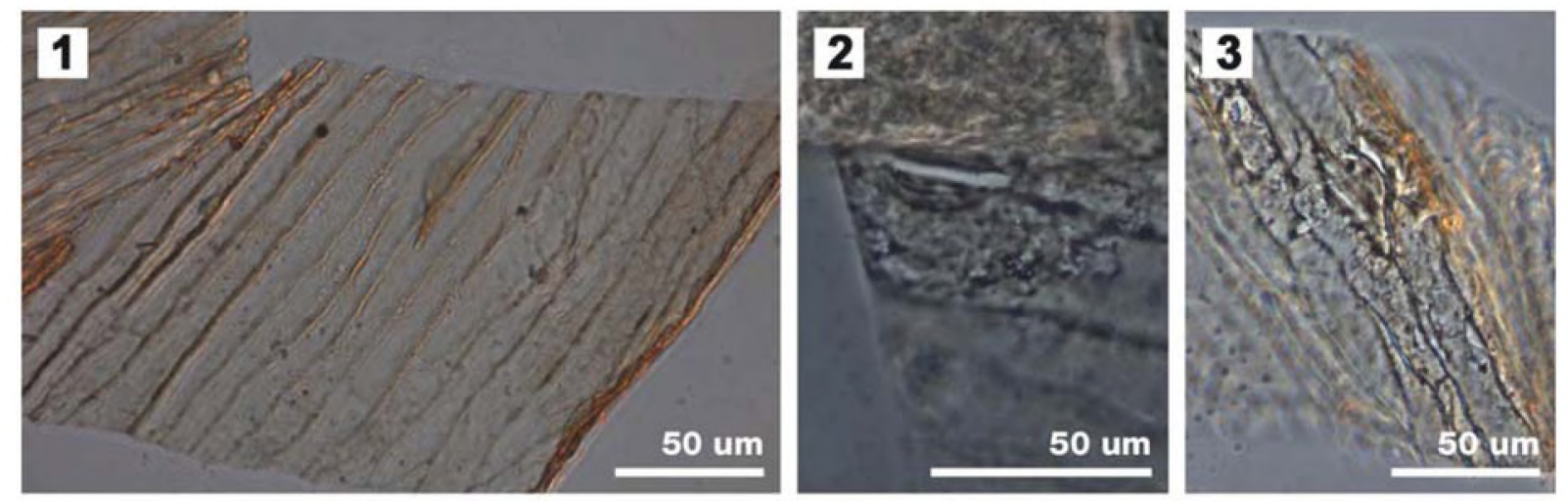

Text-fig. 4. 1 - Desmiophyllum harrisit, KRAM-P PM 139/110, lower cuticle; 2 - Desmiophyllum harrisii, KRAM-P PM 139/110, lower cuticle, detail of stoma; 3 Desmiophyllum harrisit, KRAM-P PM 139/110, lower cuticle, detail of stoma

DISCUSSION: Desmiophyllum is a heterogenic genus containing morphotypes of elongated detached leaves with parallel venation and often with an unknown cuticular structure. So far, only a few species have been described along with their cuticular structure, and most elongated leaves of this morphotype have cuticles unsuitable for preparation.

Pant et al. (1983) rejected the genus Desmiophyllum as illegitimate (as discussed in detail by these authors) and instead created Harrisophyllum, based on Seward's (1919) statement, that the type species, D. gracile possibly represents a Cordaites leaf. In fact, the cuticular structure of the type species is unknown and its different affinity has not yet been confirmed.

The genus Desmiophyllum is still in use, (e.g. Kelber and Van Konijnenburg - van Cittert 1997; Pott and McLoughlin 2011), including specimens with a preserved cuticle.

The specimens from the Huta OP-1 borehole, both in their morphological and cuticular features, differ from all known species. Harris differentiated Desmiophyllum type 2 from Greenland, based on the morphological exclusivity of the specimens, but he did not have a cuticle to justify a new species. Desmiophyllum from the Huta OP-1 borehole has identical morphology to Harris' material. The cuticle shows exceptional characteristics with extremely long cells - a feature not found in any other species (Florin 1936; Harris and Millington 1974; Lundblad 1959; Schweitzer 1977; Pott and McLoughlin 2011). The stomata resemble those of D. gothanii Florin, D. latifolium Florin (1936) or D. gramineum Harris and Millington (1974), but the gross morphology and cell pattern of the cuticles are different. D. cyclostomum Lundblad (Lundblad 1959; Pott and McLoughlin 2011) has stomata that are more similar in type to Bjuvia. The specimen from the Huta OP-1 borehole also differs from all the species de- scribed by Pant et al. (1983) as belonging to Harrisophyllum.

Ixostrobus was reported from the same locality (Huta OP-1 borehole), which is usually attributed to both Desmiophyllum or Czekanowskia leaves (Harris and Miller 1974).

\section{FLORAL SUCCESSION}

The five studied boreholes comprise five stratigraphic horizons from the Ladinian (Middle Triassic) to the Toarcian/Aalenian boundary (Table 1, Text-fig. 2). Most of the specimens are from the Hettangian (mainly Huta OP-1 borehole) and Sinemurian (mainly Studzianna borehole), and only these two boreholes can in fact be compared in more detail; the material from the other three boreholes is too poor in taxa. Even so, by describing it, we are adding to general knowledge concerning Polish Mesozoic floras.

The oldest of the described taxa is Neocalamites merianii from the Ladinian (Huta OP-1 borehole), a species common in the Late Triassic and Early Jurassic in Europe (Pott et al. 2008). Two species are reported from the Chabowo 2 borehole: Neocalamites lehmannianus and Lepidopteris ottonis. The former is also common in the Late Triassic and Early Jurassic of Europe, whereas $L$. ottonis is known mostly from the Rhaetian. The latter species shows adaptation to drier conditions (Barbacka 1991; Bonis et al. 2010) even though the climate in this period was warm and wet (Preto et al. 2010). They may represent a mesophytic type growing, e.g., on locally exposed territories.

Within the Hettangian succession, taxa from the Huta OP-1 borehole represent the lowermost part of the sequence and those from the Studzianna borehole, the uppermost part, almost at the Lower/Middle Hettangian 
boundary. Determinable plant remains occurred seldom in all of the examined borehole sequences. Plant detritus, branches or roots were observed in levels between them. During the Hettangian, the environment within the same formation in the Huta OP-1 borehole changed from meandering river floodplain to lacustrine (Pieńkowski 2004). Passing from the earliest strata containing plant remains, it is noticeable that in the floodplain species of Neocalamites and Phlebopteris angustiloba predominate. In the lacustrine environment, fern-gymnosperm plant assemblages began to dominate (conifers: Brachyphyllum and Podozamites and Ginkgophyta: Baiera and Pseudotorellia, as well as Desmiophyllum).

In the Studzianna borehole, the four formations and four facies are represented by fewer taxa than in the

\begin{tabular}{|c|c|c|c|c|c|c|c|}
\hline Taxa & \begin{tabular}{|l|} 
Studzianna \\
Ladinian
\end{tabular} & $\begin{array}{l}\text { Chabowo } 2 \\
\text { Rhaetian }\end{array}$ & $\begin{array}{l}\text { Studzianna } \\
\text { Hettangian }\end{array}$ & $\begin{array}{l}\text { Huta OP-1 } \\
\text { Hettangian }\end{array}$ & \begin{tabular}{|l|} 
Studzianna \\
Sinemurian
\end{tabular} & $\begin{array}{c}\text { Brześć } \\
\text { Kujawski } \\
\text { IG } 3 \\
\text { Sinemurian }\end{array}$ & $\begin{array}{l}\text { Ciechocinek } \\
\text { IG } 2 \\
\text { Toarcian/ } \\
\text { Aalenian }\end{array}$ \\
\hline $\begin{array}{l}\text { Neocalamites } \\
\text { lehmannianus }\end{array}$ & & + & & + & & & \\
\hline $\begin{array}{l}\text { Neocalamites } \\
\text { merianii }\end{array}$ & + & & & + & & & \\
\hline Neocalamites sp. & & & & & + & & \\
\hline $\begin{array}{l}\text { Cladophlebis } \\
\text { nebbensis }\end{array}$ & & & & + & & & \\
\hline Cladophlebis sp. & & & & & + & & \\
\hline Todites princeps & & & & + & & & \\
\hline Thaumatopteris sp. & & & & + & & & \\
\hline $\begin{array}{l}\text { Phlebopteris } \\
\text { angustiloba }\end{array}$ & & & & + & & & \\
\hline $\begin{array}{l}\text { Phlebopteris } \\
\text { muensteri }\end{array}$ & & & & & & & + \\
\hline $\begin{array}{l}\text { Coniopteris } \\
\text { hymenophylloides }\end{array}$ & & & & + & & & \\
\hline $\begin{array}{l}\text { Lepidopteris } \\
\text { ottonis }\end{array}$ & & + & & & & & \\
\hline Pachypteris sp. & & & & & + & + & \\
\hline $\begin{array}{l}\text { Ginkgoites cf. } \\
\text { marginatus }\end{array}$ & & & + & & & & \\
\hline Ginkgoites sp. & & & + & & & & \\
\hline Baiera furcata & & & & + & & & \\
\hline cf. Baiera sp. & & & & + & & & \\
\hline $\begin{array}{l}\text { Pseudotorellia } \\
\text { nordenskioeldii }\end{array}$ & & & + & & + & & \\
\hline Pseudotorellia sp. & & & & + & & & \\
\hline $\begin{array}{l}\text { Czekanowskia } \\
\text { hartzii }\end{array}$ & & & + & & & & \\
\hline $\begin{array}{l}\text { Czekanowskia } \\
\text { rigida }\end{array}$ & & & + & & & & \\
\hline $\begin{array}{l}\text { Ixostrobus } \\
\text { groenlandicus }\end{array}$ & & & & + & & & \\
\hline $\begin{array}{l}\text { Phoenicopsis } \\
\text { insolita }\end{array}$ & & & + & & + & & \\
\hline $\begin{array}{l}\text { Podozamites } \\
\text { distans }\end{array}$ & & & & + & & & \\
\hline Brachyphyllum sp. & & & & + & & & \\
\hline $\begin{array}{l}\text { Desmiophyllum } \\
\text { harrisii sp. nov. }\end{array}$ & & & & + & & & \\
\hline
\end{tabular}


Huta OP-1 borehole. From the Middle Triassic, Neocalamites merianii was identified from an alluvial environment, while the Zagaje Formation is represented by lacustrine facies and is dominated by ginkgophytes (undetermined ginkgos and Czekanowskiales: Czekanowskia and Phoenicopsis). This dominance is also observed in the Upper Hettangian Przysucha Ore-bearing Formation, probably represented by deltaic facies. The plant composition changed in the transition to the overlying Ostrowiec Formation. New elements appeared, like Cladophlebis, Pachypteris and Neocalamites, alongside taxa from the previous stage like Pseudotorellia and Phoenicopsis. It is worth noting that no other leaf forms were observed among the undetermined detritus in both localities.

A comparison of plant composition between the Studzianna and Huta OP-1 borehole successions in the same facies (Text-fig. 2) shows that there are no common elements in both floras, even major plant groups are different. Interestingly, the genera Czekanowskia, Pseudotorellia and Phoenicopsis appear relatively abundantly in the Studzianna borehole succession. These were typical representatives of the Siberian Region, where they dominated with conifers and other Ginkgoales and were associated with rather cold and dry surroundings (Vakhrameev 1991). Poland was included by Vakhrameev in the European Province, of the Euro-Sinian Region, where the Hettangian floras were characterized by rare Ginkgoales (Ginkgo, Baiera and Sphenobaiera) and even rarer Czekanowskiales. In the Late Jurassic, Czekanowskiales still dominated the Siberian Region, but in the European Province of the Euro-Sinian Region, they were absent. In a northwest direction they continued to occur in the Lower Jurassic of Greenland and the Middle Jurassic of Yorkshire (Harris 1935; Harris and Miller 1974) and Scotland (Van Konijnenburg-van Cittert and Van der Burgh 1996). Czekanowskiales were not reported from the southern European localities (Vakhrameev 1991). In Poland, Czekanowskiales are also known from the Lower Jurassic in Chmielów ( $C$. rigida and C. setacea) and in Gromadzice, near Ostrowiec (C. rigida) (Raciborski 1891, 1892; Makarewiczówna 1928). The genus Pseudotorellia was reported by Reymanówna (1963) and Wcisło-Luraniec (1989) from the Middle Jurassic of Grojec and Zabierzów.

\section{PALAEOCLIMATIC IMPLICATIONS}

Generally, plants react to changes in their surroundings by adaptation of their morphology or internal structures (e.g. Van Konijnenburg-van Cittert 2002, Theve- nard et al. 2005, Abbink et al. 2004, Barbacka et al. 2010) or by succession of taxa specialized to life in given circumstances (e.g. Vakhrameev 1991, Taylor et al. 2009). While in the case of sporadic remains only individual adaptations can be detected, investigation of plant assemblages may result in extended conclusions about their environments and climatic changes.

The co-occurrence of three Siberian genera in the Studzianna borehole flora suggests that over a relatively short period (probably less than 1 million years, but possibly a few hundred thousand, in the late Early Hettangian and earliest Middle Hettangian), the climate became colder and drier (Text-fig. 2). Such a time interval was long enough for floristical change. The difference between the Studzianna and Huta OP-1 borehole floras in this case might be a result of the slight shift in age between both localities (Studzianna is a little later Early Hettangian; Brański personal communication) which, without climate instability could not be detectable by any change in floristical composition. Additionally, in both localities plant remains were allochthonous, but even though they were in close geographical proximity to each other, they belonged to two different river systems. The Studzianna area was located near the Zawada Delta System and was supplied with sediments from a northeast direction (East European Craton), while the area occupied by today's Huta OP-1 borehole was sheltered (initially lake-swamp, then after transgression, semi-closed bay and lagoon) and rivers supported this territory mostly from the south (Pieńkowski 2004, figs 24 and 48, Brański personal communication). Taphonomical observation of plant remain fragmentation confirms that the Studzianna environment was characterized by higher energy (influenced by a nearby river, which broke up the material to a high degree, often into detritus form), while Huta OP-1 was characterized by a lower energy environment, which is indicated by the larger and more complete fragments of delicate organs (e.g. fern fronds, Ixostrobus catkins).

The possibility of certain climatic changes during the Hettangian has been proposed based on clay mineral study, especially of the kaolinite/illite ratio in the sediments of the Przysucha Ore-bearing Formation, Skłoby Formation and Zagaje Formation in the Holy Cross Mts. margin, which was studied in the Huta OP-1 borehole, among others (Brański 2009, 2011; Brański personal communication). The kaolinite/illite ratio indicates an erosion intensity which depends, among other factors, on wetness and the temperature of the environment. The fluctuations in the kaolinite content confirm a decrease in temperature and reduction in rainfall in the late Early Hettangian (Brański 2011) and in the latest Hettangian (Brański 2009). 
The diversity of plant assemblages on a given territory may depend not only on climatic instabilities, but also on various conditions within ecological niches. These may be influenced by elevation, distance from the sea coast (influence of salty water), marine transgression and regression, distance from fresh water, air humidity, and soil moisture and properties. In fact, the different direction of the slopes and their exposure to sun radiation (sunny south facing - shaded north facing) may cause significant dissimilarities in temperature (Patzkowsky and Holland 2012).

Although these factors should be taken into consideration, it seems that the taxonomic content of the flora from Studzianna tends to reflect the temporal climatic change suggested by Brański (op. cit.) and was not of a local mesophytic character.

\section{CONCLUSIONS}

1. Macrofloral remains from five boreholes of different Triassic and Jurassic strata (from the Toarcian to Sinemurian) were examined for the first time. The drilling cores originated from the Studzianna and Huta OP-1 boreholes (margin of the Holy Cross Mountains), the Ciechocinek IG 1 and Brześć Kujawski IG 3 boreholes in central Poland, and the Chabowo 2 borehole in the Szczecin region. Only in the Studzianna and Huta OP-1 boreholes (lower part of Lower Jurassic) was the number of taxa suitable for floristical, ecological or climatic interpretations.

2. The macroremains in the Huta OP-1 borehole were found in the lowermost Hettangian Zagaje Formation, the deeper part of which was represented by meandering river facies and the higher part by lacustrine facies. At Studzianna, the macroremains came from the upper Lower Hettangian (Zagaje Formation), Upper Hettangian (Przysucha Ore-bearing Formation) and Sinemurian (Ostrowiec Formation).

3. Significant differences in plant composition between Studzianna and Huta OP-1 were observed. Huta OP1 was fern-dominated, passing into conifer-dominated (typical Euro-Sinian Region, European Province), while in Studzianna Siberian elements like Czekanowskiales dominated.

4. The plant assemblages from both localities indicate different environmental conditions. Those from Huta OP-1 exhibited association with warm and wet conditions and those from Studzianna with rather cold and dry conditions.

5. Unexpected floristical differences in localities of relatively close proximity and similar age (partly within the same formation) can be explained by one of the climatic changes proved by clay mineral studies, in particular the kaolinite/illite ratio, which confirms a decrease in temperature and reduction in rainfall in the later Early Hettangian and latest Late Hettangian.

\section{Acknowledgments}

We would like to express our thanks to Johanna H.A. van Konijnenburg-van Cittert, Mihai Popa and Natalya Nosova for their helpful suggestions regarding the taxonomic work. We are also grateful to Paweł Brański for fruitful discussion and for the advice he provided on the palaeoecological interpretations, and to Danuta Zdebska for her suggestions during preparation of the manuscript. We would also like to thank B. Kietlińska-Michalik, for placing Raciborski's original material at our disposal. We are very grateful to Marian Szewczyk for his good quality macro photographs and Michał Szewczyk for preparing the plates. Agnieszka Sojka skillfully prepared the text-figures. We would like to thank Philip Palmer for linguistic correction of the manuscript.

The present investigations were supported by funds for scientific research granted by the Ministry of Science and Higher Education, Poland (Grant no N N303 373036, 2009-2013) and by the W. Szafer Institute of Botany, Polish Academy of Sciences through its statutory funds.

\section{REFERENCES}

Abbink O., Van Konijnenburg-van Cittert J.H.A. and Visscher H. 2004. A sporomorph ecogroup model of the Northwest European Jurassic - Lower Cretaceous: concepts and framework. Geologie en Mijnbouw, 83, 17-38.

Anderson, J.M., Anderson, H.M. and Cleal, C.J. 2007. Brief history of the gymnosperms: classification, biodiversity, phytogeography and ecology. Strelitzia, 20, 1-280.

Antevs, E. 1914. Lepidopteris ottonis (Göpp.) Schimp. and Antholithus zeilleri Nath. Kungliga Vetesnskapsakademien Handlingar, 51, 1-18.

Antevs, E. 1919. Die liassische Flora des Horsandsteins. Kungliga Vetesnskapsakademien Handlingar 59, 1-71.

Barbacka, M. 1991. Lepidopteris ottonis (Goepp.) Schimp. and Peltaspermum rotula Harris from the Rhaetian of Poland. Acta Palaeobotanica, 31, 23-47.

Barbacka, M. 2002. The Liassic Ginkgoales from the Mecsek Mountains, Hungary. Revue de Paléobiologie 21, 697-715.

Barbacka, M. 2011. Biodiversity and the reconstruction of Early Jurassic flora from the Mecsek Mountains (southern Hungary). Acta Palaeobotanica, 51, 127-179.

Barbacka, M. and Bodor, E. 2008. Systematic and palaeoenvironmental investigations of fossil ferns Cladophlebis 
and Todites from the Liassic of Hungary. Acta Palaeobotanica, 48, 133-149.

Barbacka, M. and Bóka, K. 2014. Ovule containing cupules belonging to the Early Jurassic pteridosperm Komlopteris nordenskioeldii Nathorst) Barbacka. Review of Palaeobotany and Palynology, 210, 102-112.

Barbacka, M., Ziaja, J., Wcisło-Luraniec, E. and Reymanówna, M. 2007. Hirmeriella muensteri (Schenk) Jung from Odrowąż (Poland), with female and male cones, and in situ Classopolis pollen grains. Acta Palaeobotanica, 47, 339357.

Barbacka, M., Ziaja, J. and Wcislo-Luraniec, E. 2010. Taxonomy and palaeoecology of the Early Jurassic macroflora from Odrowąż, central Poland. Acta Geologica Polonica, 60, 373-392.

Berchtold, F. Graf von and Pres1, J.C. 1820. O Prirozenosti Rostlin aneb Rostlinar, pp. 1-322. Krala Wiljma Endersa; Prague.

Bessey, C. E. 1907. A synopsis of plant phyla. University of Nebraska Studies, 7, 275-373.

Black, M. 1929. Equisetites in position of growth in the Sundance Limestone. American Midland Naturalist, 11, 534541.

Bomfleur, B., Pott, C. and Kerp, H. 2011. Plant assemblages from the Shafer Peak Formation (Lower Jurassic), North Victoria Land, Transantarctic Mountains. Antarctic Science, 23, 188-208.

Bonis, N.R., van Konijnenburg-van Cittert, J.H.A. and Kürschner, W.M. 2010. Changing $\mathrm{CO}_{2}$ conditions during the end-Triassic inferred from stomatal frequency analysis on Lepidopteris ottonis (Goeppert) Schimper and Ginkgoites taeniatus (Braun) Harris. Palaeogeography, Palaeoclimatology, Palaeoecology, 295, 146161.

Bose, M. N. and Banerji, J. 1984. The fossil floras of Kachchh. I. Mesozoic megafossils. Palaeobotanist, 33, 1-189.

Bose, M.N. and Manum, S.B.1990. Mesozoic conifer leaves with Sciadopitys-like stomatal distribution. A reevaluation based on fossils from Spitsbergen, Greenland and Baffin Island. Norsk Polarinstitutt Skrifter, 192, 1-81.

Bower, F.O. 1908. The origin of a land flora: a theory based upon the facts of alternation, 1-727. Macmillan; London.

Brański, P. 2009. Influence of palaeoclimate and the greenhouse effect on Hettangian clay mineral assemblages (Holy Cross Mts. area, Polish Basin). Geological Quarterly, 53, 363-368.

Brański, P. 2011. Clay mineral composition in the Triassic and Jurassic deposits from the Polish Basin - a record of palaeoclimatic and palaeoenvironmental changes. Biuletyn Państwowego Instytutu Geologicznego 444, 15-32. [In Polish with English abstract]

Braun, C.F.1843. Beiträge zur Urgeschichte der Pflanzen. In: Münster, G. (Ed.), Beiträge zur Petrefactenkunde 6, 1-33.
Brongniart, A. 1828-1837. Histoire des végétaux fossiles ou recherches botaniques et géologiques sur les végétaux renfermés dans les diverses couches du globe, Vol. I, pp. 1488, Vol. II, pp. 1-72, Atlas: $166+30$ plates, G. Dufour et Ed. d'Ocagne (Vol. I), Crochard et Compagnie (Vol. II), Paris.

Brongniart, A. 1849. Tableau des genres de végétaux fossiles considérés sous le point de vue de leur classification botanique et de leur distribution géologique, pp. 1-127. Martinem; Paris.

Candolle, A.-P. de 1804. Essai sur les propriétés médicales des plantes, pp. 1-148. Didot Jeune; Paris.

Cronquist, A., Takhtajan, A. and Zimmermann, W. 1966. On the higher taxa of Embryobionta. Taxon, 15, 129-134.

Doludenko, M.P. and Samylina, V.A. 1992. New species of Pseudotorellia from the Middle Jurassic of Karatau, Southern Kazakhstan. Paleontologicheskij Zhurnal, 4, 5357.

Dumortier, B.C.J. 1829. Analyse des familles des plantes, pp. 1-104. Casterman; Tournay.

Dunker, W. 1846. Monographie der Norddeutschen Wealdenbildung. pp. 1-83. Verlag von Oehme und Müller; Braunschweig.

Feldman-Olszewska, A. 2008a. Detailed lithologicaly-stratigraphical profile of the Brześć Kujawski IG 3 borehole. Lower Jurassic. In: Brześć Kujawski IG 1, IG 2, IG 3. Profile Gtębolich Otworów Wiertniczych Państwowego Instytutu Geologicznego, 125, 110-123. [In Polish]

Feldman-Olszewska, A. 2008b. Results of the Lower Jurassic deposits lithological and stratigraphical investigations. In: Brześć Kujawski IG 1, IG 2, IG 3. Profile Glębokich Otworów Wiertniczych Państwowego Instytutu Geologicznego, 125, 139-140. [In Polish]

Florin, R. 1936. Die fossilen Ginkgophyten von Franz-JosephLand nebst Erörterungen über vermeintliche Cordaitales mesozoischen Alters. II. Allgemeiner Teil. (Schluß der Arbeit). Palaeontographica B, 82, 1-72.

Gajewska, I. 1978. The stratigraphy and development of the Keuper in north-west Poland. Prace Instytutu Geologicznego, 87, 5-59. [In Polish with English Summary]

Gajewska, I. 1997a. The Upper Triassic. The Keuper. Rock formation, stratigraphy and paleogeography. In: Epikontynentalny perm i mezozoik w Polsce. Prace Państwowego Instytutu Geologicznego, 153, 166-172. [In Polish with English summary]

Gajewska, I. 1997b. The Middle Triassic (Muschelkalk and Lower Keuper). Rock formation, stratigraphy and paleogeography. In: Epikontynentalny perm i mezozoik w Polsce. Prace Państwowego Instytutu Geoleologicznego, 153, 144-150. [In Polish with English summary]

Gee, C. 1989. Revision of the Late Jurassic/Early Cretaceous flora from Hope Bay, Antarctica. Palaeontographica B, 213, 149-214. 
Goeppert, H.R. 1836. Die fossilien Farnkräuter (Systema filicum fossilium). Nova Acta Leopoldina Supplementum, 17, $1-486$.

Goeppert, H. 1841-1846. Die Gattungen der fossilen Pflanzen. Les generes des plantes fossiles. pp. 1-154. Verlag von Henry und Cohen; Bonn.

Goeppert, H. 1846. Ueber die fossile Flora der mittleren Juraschichten in Obreschlesien. Uebersicht der Arbeiten und Veränderungen der Schlesischen Gesellschaft für vaterländische Cultur im Jahre 1845, 139-149.

Gomolitzky, N.P. 1965. New Middle Jurassic Ferns and Ginkgolean of the Gissarskii Range. Paleontologicheskij Zhurnal, 1, 125-132.

Gorozhankin, I.N. 1904. Lekcii po morfologii i sistematiki arhegonial'nyh rastenij. II. Pteridophyta, pp. 73-93. Mamontov; Moscow. [In Russian]

Gothan, W. 1909. In: Potonié, H. (Ed.), Abbildungen Beschreibungen fossiler Pflanzen Reste, 6, 1-5.

Gothan, W. 1914a. Die unter-liassische (rhätische) Flora der Umgegend von Nürnberg. Abhandlungen der Naturhistorischen Gesellschaft zu Nürnberg, 19, 89-186.

Gothan, W. 1914b. Über die Gattung Thinnfeldia Ettingshausen. Abhandlungen der Naturhistorischen Gesellschaft zu Nürnberg, 19, 67-88.

Halle, T.G. 1908. Zur Kenntnis der Mesozoischen Equisetales Schwedens. Kungliga Svenska Vetenskapsakademiens Handlingar, 43, 1-38.

Halle, T.G. 1913. The Mesozoic Flora of Graham Land. In: Nordenskjöld, O. (Ed.), Naturwissenschaflische Ergebnisse der schwedischen Südpolar-Expedition 1901-1903, 3, pp. 1-123.

Harris, T.M. 1926. The Rhaetic flora of Scoresby Sound, East Greenland. Meddelelser om Grønland, 68, 45-148.

Harris, T.M. 1931. The Fossil Flora of Scoresby Sound East Greenland, 1: Cryptogams (Exclusive of Lycopodiales). Meddelelser om Grønland, 85, 1-102.

Harris, T.M., 1932. The fossil flora of Scoresby Sound East Greenland, 2: Description of seed plants incertae sedis together with a discussion of certain Cycadophyte cuticles. Meddelelser om Grønland, 85, 1-114.

Harris T.M. 1935. The fossil flora of Scoresby Sound East Greenland. Part 4: Ginkgoales, Coniferales, Lycopodiales and isolated fructifications. Meddelelser om Gronland, 112, 1-176.

Harris, T.M. 1937. The fossil flora of Scoresby Sound East Greenland. Part 5: Stratigraphic relations of the plant bed. Meddelelser om Gronland, 112, 1-114.

Harris, T.M. 1961. The Yorkshire Jurassic Flora I: Thallophyta - Pteridophyta, pp. 1-212. Trustees of the British Museum (Natural History); London.

Harris, T.M. and Millington, W. 1974. The Yorkshire Jurassic flora IV. Ginkgoales pp. 1-78. Trustees of the British Museum (Natural History); London.
Harris, T.M. and Miller, J. 1979. The Yorkshire Jurassic flora IV. Czekanowskiales, pp. 79-150. Trustees of the British Museum (Natural History); London.

Heer, O. 1876. Beiträge zur Jura-Flora Ostsibiriens und des Amurlandes. Memoires de l'Académie Impériale des Sciences de St.Péterbourg. VII Série 22, 1-122.

Hirmer, M. and Hörhammer, L. 1936. Morphologie Systematik und geographische Verbreitung der fossilen und rezenten Matoniaceen. Palaeontographica, B 81, 1-70.

Hisinger, W. 1840. Lethaea svecica seu Petrifacta svecicae: Supplementum secundum, pp. 1-12. P.A. Norstedt; Holmiae.

Jaeger G.F. 1827. Über die Pflanzenversteinerungen welche in dem Bausandstein von Stuttgart vorkommen. Verlag der J.B. Metzelerschen Buchhandlung; Stuttgart.

Jarzynka, A. 2012. The middle Jurassic flora of the Grojec clays - taxonomy and palaeoecology, pp. 1-196. PhD Thesis, Instytut Botaniki im. W. Szafera, Polska Akademia Nauk; Kraków. [In Polish]

Johansson, N. 1922. Die rätische Flora der Kohlengruben bei Stabbarp und Skomberga in Schonen. Kungliga Svenska Vetenskapsakademiens Handlingar, 63, 1-78.

Karaszewski, W. 1962. The stratigraphy of the Lias in the northern Mesozoic zone surrounding the Święty Krzyż Mountains (Central Poland). Prace Instytutu Geologicznego, 30, 333-416. [In Polish with English Sumary]

Karaszewski W. and Kopik J. 1970. Lower Jurassic. In: The Stratigraphy of the Mesozoic in the margin of the Góry Świętokrzyskie. Prace Instytutu Geologicznego, 56, 66-98. [In Polish, with English summary]

Kelber, K.P. and Van Konijnenburg-van Cittert, J.H.A. 1997. A new Rhaetian flora from the neighbourhood of Coburg (Germany) - preliminary results. Mededelingen Nederlands Institut voor Toegepaste Geovetenschappen, $\mathbf{5 8}$, 105-114.

Kelber, K.-P. and Hansch, W. 1995. Keuperpflanzen. Die Enträtselung einer über 200 Millionen Jahre alten Flora. Museo, 11, 1-157.

Kilpper, K. 1964. Über eine Rät-Lias-Flora aus dem nördlischen Abfall des Alburs-Gebirges in Nordiran. 1: Bryophyta und Pteridophyta. Palaeontographica, B 114, 1-78.

Kilpper, K. 1971. Über eine Rät/Lias-Flora aus dem nördlichen Abfall des Alburs-Gebirges in Nord-Iran. 2. GinkgophytenBelaubungen. Palaeontographica, B 133, 89-102.

Kirchner, M. 1992. Untersuchungen an einigen Gymnospermen der Fränkischen Rhät-Lias-Grenzschichten. Palaeontographica, B 224, 17-61.

Kiritchkova, A.I. and Nosova, N.V. 2009. The Genus Pseudotorellia Florin (Ginkgoales): Taxonomic and Stratigraphic Aspects. Stratigraphy and Geological Correlation, 17, 615-631.

Kiritchkova, A.I. and Nosova N.V. 2012. Jurassic continental deposits of the Middle-Caspian Basin. 2: Facies, taphon- 
omy, interregional correlations, flora (Pinophyta: Pteridospermae, Cycadales, Bennettitales, Ginkgoales, Czekanowskiales, Coniferales), pp. 1-338. Vnigri, St. Petersburg. [In Russian, English summary and descriptions of new taxa]

Van Konijnenburg-van Cittert, J.H.A.1993. A review of the Matoniaceae based on in situ spores. Review of Palaeobotany and Palynology, 78, 235-267.

Van Konijnenburg-van Cittert J.H.A. and J. van der Burgh, 1996. Review of the Kimmeridgian flora of Sutherland, Scotland, with special reference to the ecology and in situ pollen and spores. Proceedings Geologists'Association, 107, 97-105.

Van Konijnenburg-van Cittert, J.H.A. and Morgans, H.S. 1999. The Jurassic flora of Yorkshire. Palaeontological Association Field Guides to Fossils 8, pp. 1-134. Palaeontological Association; London.

Van Konijnenburg-van Cittert J.H.A. 2002. Ecology of some Late Triassic to Early Cretaceous ferns in Eurasia. Review of Palaeobotany and Palynology, 119, 113-124.

Kostina, E.I. 2004. Jurassic flora of the Kansky carboniferous basin [in Russian]. Proceedings of the Geological Institute of the Russian Academy of Science 564, pp. 1-166. GEOS; Moscow.

Krassilov, V.A. 1970. Approach to the classification of Mesozoic "Ginkgoalean" plants from Siberia. The Palaeobotanist, 18, 12-19.

Krassilov, V.A. 1972. Mesozoic flora of the Bureja River (Ginkgoales and Czekanowskiales), pp. 1-151. Nauka; Moscow. [In Russian]

Kräusel, R. 1958. Die Juraflora von Sassendorf bei Bamberg. I. Sporenpflanzen. Senckenbergiana lethaea, 39, 67-103.

Kräusel, R. 1959. Die Keuperflora von Neuewelt bei Basel. III. Equisetaceen. Schweizerischen Paläontologischen $A b$ handlungen, 77, 5-19.

Lesquereux, L. 1878. On the Cordaites and their related generic divisions, in the Carboniferous Formation of the United States. Proceedings of the American Philosophical Society, 17, 315-335.

Lindley, J. and Hutton W. 1837. The fossil flora of Great Britain, or figures and descriptions of the vegetable remains found in the fossil state in this country, vol. 3, pp. 157-230. James Ridgway and sons, Picadilly; London.

Lundblad, A.B. 1950. Studies in the Rhaeto-Liassic floras of Sweden. I. Pteridophyta, Pteridospermae and Cycadophyta from the mining district of NW Scania. Kungliga Svenska Vetenskapsakademiens Handlingar, Ser. 4, 1, 182.

Lundblad, B. 1957. On the presence of the genus Pseudotorellia (Ginkgophyta) in the Rhaetic of N.W. Scania. Geologiska Föreningens i Stockholm Förhandlingar, 79, $758-765$.

Lundblad, B. 1959. Studies in the Rhaeto-Liassic floras of Swe- den. II: 1. Ginkgophyta from the mining district of NW Scania Kungliga Svenska Vetenskapsakademiens Handlingar, Ser. 4, 6, 1-38.

Lundblad, B. 1968. The present status of the genus Pseudotorellia Florin (Ginkgophyta). Journal of the Linnean Society of London (Botany), 61, 189-195.

Makarewiczówna, A. 1928. Etude sur la flore fossile du lias inférieur des environs d'Ostrowiec. Travaux de la Saciété des Science et des Letters de Wilno, Travaux de L'Institut de Géologie de l'Université de Wilno, 4, 1-49. [In Polish with French summary]

Marcinkiewicz, T. and Orłowska-Zwolińska, T. 1994. Miospores, megaspores and Lepidopteris ottonis (Goeppert) Schimper in the uppermost Triassic deposits from Poland. Geological Quarterly, 38, 91-116.

Meyen, S.V. 1987. Fundamentals of palaeobotany, pp. 1-432. Chapman and Hall; London - New York.

Miller, I.M. and Hickey, L.J. 2010. The fossil flora of the Winthrop Formation (Albian-Early Cretaceous) of Washington State, USA. Part II: Pinophytina. Bulletin of the Peabody Museum of Natural History, 51, 3-96.

Nagy, I.Z. 1961. Liassic remains of the Mecsek Mountains. Annales Instituti Publici Geologiae Hungarici, 49, 609-613.

Narkiewicz M. and Dadlez, R. 2008. Geological regional subdivision of Poland: general guidelines and proposed schemes of sub-Cenozoic and sub-Permian units Przeglad Geologiczny, 56, 391-397. [In Polish with English abstract]

Nathorst, A.G. 1876. Bidrag till sveriges fossila flora. Kungliga Svenska Vetenskapsacademiens Handlingar, 14, 1-82.

Nathorst, A.G. 1878a. Om floran i Skånes kolförande bildningar 1. Floran vid Bjuf, första häftet. Sveriges Geologiska Undersökning C, 27, 1-52.

Nathorst, A.G. 1878b. Bidrag till Sveriges fossila flora 2. Floran vid Höganäs och Helsingborg. Kungliga Svenska Vetenskapsakademiens Handlingar, 16, 1-53.

Nathorst, A.G. 1886. Om floran i Skånes kolförande bildningar. Sveriges Geologiska Undersökning C, 85, 85-131.

Nathorst, A.G. 1906. Om nagra Ginkgo-växter fran kolgrufvorna vid Stobbarp i Skane. Lunds Universität Arsskrift, Neues Folge, 2, 2, 8, 1-15.

Nosova, N.V. and Kiritchkova, A.I. 2011. New species of Phoenicopsis (Czekanowskiales) from the Jurassic of Mangyshlak (Kazakhstan). Paleobotany, Vol., 2, 114-127. Maraphon; St. Petersburg. [In Russian with English summary]

Oliver, F. W. and Scott, D.H. 1904. On the structure of the Palaeozoic seed Lagenostoma lomaxi, with a statement of the evidence upon which it is referred to Lyginodendron. Philosophical Transactions of the Royal Society of London, 197, 193-247.

Orlovskaja, E.R. 1962. The finds of Pseudotorellia and Eretmophyllum in the Jurassic deposits of Kazakhstan. Botanicheski Journal, 47, 1437-1445.

Pacyna, G. 2013. Critical review of research on the Lower 
Jurassic flora of Poland. Acta Palaeobotanica, 53, 141163.

Pacyna, G. and Zdebska, D. 2011. New data on the genus Ixostrobus Raciborski 1892 (gymnosperms, Czekanowskiales?) from the early Jurassic of Gromadzice (The Holy Cross Mountains). In: B.A. Matyja, A. Wierzbowski and Ziółkowski P. (Eds), Jurassica IX, Materiały konferencyjne, Artykuly, Malogoszcz, 06-08.09.2011, pp. 33-39. Polskie Towarzystwo Geologiczne, Polska Grupa Robocza Systemu Jurajskiego. [In Polish]

Patzkowsky, M. E. and Holland, S. M. 2012. Stratigraphic paleobiology. Understanding the distribution of fossils taxa in time and space, pp. 259. University Chicago Press; Chicago - London.

Pant, D.D., Srivastava, G.K. and Pant, R. 1983. On the cuticular structure of leaves of Desmiophyllum type from Bansa beds, India and their assignment to genus Harrisophyllum nov. Palaeontographica, B 185, 38-55.

Petriella, B. 1981. Sistematica y vinculaciones de las Corystospermaceae H. Thomas. Ameghiniana, 18, 221-234.

Pieńkowski, G. 1983. Early Lias sedimentary environments at northern margin of the Holy Cross Mts. Przeglad Geologiczny, 4, 223-231. [In Polish with English Summary]

Pieńkowski, G. 2004. The epicontinental Lower Jurassic of Poland. Polish Geological Institute Special Papers, 12, 1122.

Piwocki, M. 1970. Lepidopteris ottonis from the Rhaetic deposits of the southern part of the Fore-Sudetic monocline. Kwartalnik Geologiczny, 1, 101-106. [In Polish with English Summary]

Pott, C. and McLoughlin, S. 2011. The Rhaetian flora of Rögla, Northern Scania, Sweden. Palaeontology, 54, 1025-1051.

Pott, C., Kerp, H. and Krings, M. 2008. Sphenophytes from the Carnian (Upper Triassic) of Lunz am See (Lower Austria). Jahrbuch der Geologischen Bundesanstalt, 148, 183-199.

Presl, C. 1847. Die Gefäßbündel im Stipes der Farne, 1-48. Königlich-Kaiserliche Hofbuchdruckerei von Gottlieb Haase; Prague.

Preto, N., Kustatscher, E. and Wignall, P.B. 2010. Triassic climates - state of the art and perspectives. Palaeogeography, Palaeoclimatology, Palaeoecology, 290, 1-10.

Raciborski, M. 1890. The Rhaetic flora of the Tatra Mountains. Rozprawy Wydzialu Matematyczno-Przyrodniczego Akademii Umiejętności w Krakowie, 21, 243-260. [In Polish]

Raciborski, M. 1891. Rhaetic flora from the northern slope of the Holy Cross Mountains. Rozprawy Wydzialu matematyczno-przyrodniczego Akademii Umiejętności w Krakowie, 23, 292-326. [In Polish]

Raciborski M. 1892. Supplement to the Rhaetic flora of Poland. Rozprawy Wydzialu matematyczno-przyrodniczego Akademii Umiejętności w Krakowie, 22, 345-360. [In Polish]

Raciborski, M. 1894. The fossil flora of the Grojec Clay
Formation. I. (Archaegoniatae). Pamiętnik matematyczno-przyrodniczy Akademii Umiejętności, 18, 1-101. [In Polish]

Reymanówna, M. 1963. The Jurassic flora from Grojec near Cracow in Poland. Part I. Acta Palaeobotanica, 4, 9-48.

Reymanówna, M. 1992. Two conifers from the liassic flora of Odrowąż in Poland. In: J. Kovar-Eder (Ed.), Palaeovegetational development in Europe and regions relevant to its palaeofloristic evolution, Proceedings Pan-European Palaeobotanical Conference, pp. 307-311. Museum of Natural History; Vienna.

Roemer, F. 1870. Geologie von Oberschlesien, pp. 1-587. Druck von Robert Nischkowsky; Breslau.

Samylina, V.A., Kiritchkova, A.I. 1991. The genus Czekanowskia. pp. 1-144. Nauka; Leningrad. [In Russian]

Schenk A. 1867. Die fossile flora der Grenzschichten des Keupers und Lias Frankens, pp. 232. Kreidel's Verlangen; Wiesbaden.

Schimper, W. 1869. Traité de Paléontologie Végétale ou la Flore du Monde Primitif dans ses Rapports avec les Formations Géologiques et la Flore du Monde Actuel, vol. 1, pp. 1-740. J.B. Bailliére et Fils; Paris.

Schweitzer, H-J. 1977. Die Räto-Jurassischen Floren des Iran und Afganistans. 4. Die Rätische Zwitterblütte Irania hermafroditica nov.spec. und ihre Bedeutung für die Phylogenie der Angiospermen. Palaeontographica, B 161, 98145.

Schweitzer, H-J.1978. Die Räto-Jurassischen Floren des Iran und Afganistans. 5. Todites princeps, Thaumatopteris brauniana und Phlebopteris polypodioides. Palaeontographica, B 168, 17-60.

Schweitzer, H-J., Kirchner, M. 1995. Die Räto-Jurassischen Floren des Iran und Afganistans: 8. Ginkgophyta. Palaeontographica, B 237, 1-58.

Schweitzer, H-J., van Konijnenburg-van Cittert, J. and van der Burgh, J. 1997. The Rhaeto-Jurassic flora of Iran and Afghanistan. 10. Bryophyta, Lycophyta, Sphenophyta, Pterophyta-Eusporangiatae and -Protoleptosporangiatae. Palaeontographica, B 243, 103-192.

Schweitzer, H. J., Schweitzer, U., Kirchner, M., van Konijnenburg-van Cittert, J. H. A. and Ashraf, R. A. 2009. The Rhaeto-Jurassic flora of Iran and Afghanistan. 14. Pterophyta - Leptosporangiatae. Palaeontographica, B 279, $1-108$.

Scott, D. H. 1900. Studies of fossil botany, pp. 1-533. A\&C Black; London.

Seward, A.C. 1900. The Jurassic flora I. The Yorkshire coast. Catalogue of the Mesozoic Plants in the Department of Geology, British Museum (Natural History), 3, 1-341.

Seward, A.C. 1919. Fossil plants IV. Ginkgoales, Coniferales, Gnetales. pp. 1-543. Cambridge University Press; Cambridge.

Seward, A.C. and Dale, E. 1901. On the structure and affini- 
TRIASSIC-JURASSIC FLORA OF POLAND

ties of Dipteris, with notes on the geological history of Dipteridinae. Philosophical Transactions of the Royal Society of London, 194, 487-513.

Sternberg, K.M. 1820-1838. Versuch einer geognostischbotanischen Darstellung der Flora der Vorwelt. Vol. I (14) and II (5-8), pp. 1-220. Fleischer; Leipzig.

Taylor, T.N. 1981. Paleobotany: An introduction to fossil plant biology, pp. 1-589. McGraw Hill; New York.

Taylor, T. N., Taylor, E. L. and Krings, M. 2009. Paleobotany: The biology and evolution of fossil plants, Second Edition, pp. 1-1230. Academic Press; Burlington.

Thévenard, F., Gomez, B. and Daviero-Gomez, V. 2005. Xeromorphic adaptations of some Mesozoic gymnosperms. A review with palaeoclimatological implications. Comptes Rendus Palevol, 4, 67-77.

Thomas, H.H. 1932. On some Pteridospermous plants from the Mesozoic rocks of South Africa. Philosophical Transactions of the Royal Society of London, 222, 483493.

Tralau, H. 1965. Phlebopteris angustiloba (Presl) Hirmer et Hörhammer (Matoniaceae) from "Olstorp" Shaft, Bjuv, Scania. Botaniska Notiser, 118, 373-376.

Vakhrameev, V.A. 1991. Jurassic and Cretaceous floras and climates of the Earth, pp. 1-318. Cambridge University Press; Cambridge.

Vakchrameev, V. A. and Doludenko M. P. 1961. Upper Juras- sic and Lower Cretaceous flora of the Bureja River Basin and its stratigraphic significance. Trudy Geologicheskii Institut Akademia Nauk SSSR, 54, 1-134.

Wcisło-Luraniec, E. 1985. New details of leaf structure in Bilsdalea dura Harris (Coniferae) from the Jurassic of Kraków, Poland. Acta Palaeobotanica, 25, 13-20.

Wcisło-Luraniec, E. 1989. Pseudotorellia tenuis n. sp. (Ginkgoales) from the Jurassic of the Kraków region. Acta Palaeobotanica, 29, 207-211.

Wcisło-Luraniec, E. 1992. Flora from Odrowąż in Poland - a typical lower Liassic European flora. In: J. Kovar-Eder (Ed.), Palaeovegetational development in Europe and regions relevant to its palaeofloristic evolution. Proceedings Pan-European Palaeobotanical conference, 331-335. Museum of Natural History; Vienna.

Wcisło-Luraniec, E. and Barbacka, M. 2000. Lxostrobus grenlandicus Harris from Hungarian Liassic with reference to revision of the genus Lxostrobus from Poland. Acta Palaeobotanica, 40, 35-38.

Weber, R. 1968. Die fossile Flora der Rhät-lias-Übergangsschichten von Bayreuth (Oberfranken) unter besonderer Berücksichtigung der Coenologie. Erlanger Geologische Abhandlungen, 72, 1-73.

Ziaja, J. 2006. Lower Jurassic spores and pollen grains from Odrowąż, Mesozoic margin of the Holy Cross Mountains, Poland. Acta Palaeobotanica, 46, 3-83 


\section{PLATE 1}

1 - Neocalamites lehmannianus Muz. Geol. PIG 1794.II.3 (Chabowo 2, 1220.0 m);

2 - Neocalamites lehmannianus KRAM-P PM 139/339 (Huta OP-1, 171.8-172.8 m); 3 - Neocalamites lehmannianus KRAM-P PM 139/333 (Huta OP-1, 171.8-172.8 m); 4 - Neocalamites merianii KRAM-P PM 138/15A (Studzianna, $1661.0 \mathrm{~m}$ ); 5 - Neocalamites merianii KRAM-P PM 138/15B (Huta OP-1, 171.8-172.8 m); 6 - Neocalamites merianii KRAM-P PM 139/124/I (Huta OP-1, 169.0 m); 7 - Neocalamites meriani KRAM-P PM 139/225 (Huta OP-1, 102.6 m); 8 - Neocalamites meriani KRAM-P PM 139/337 (Huta OP-1, 164.0-165.3 m) 

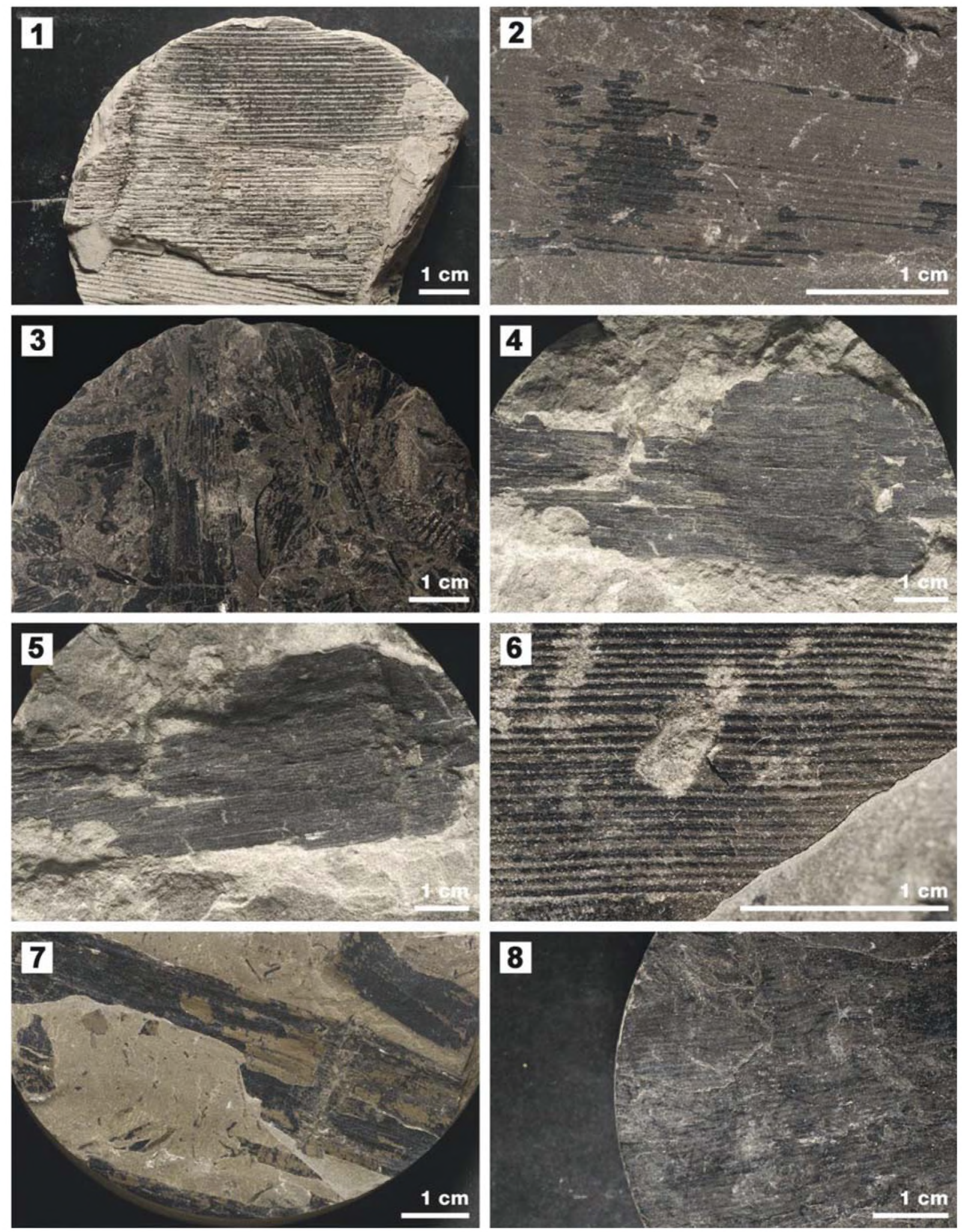


\section{PLATE 2}

1 - Neocalamites sp. KRAM-P PM 138/72/I (Studzianna, 772.0 m); 2 - Neocalamites sp. KRAM-P PM 138/72/I detail; 3 -Cladophlebis nebbensis KRAM-P PM 139/103 (Huta Op-1, 76.3 m); 4 - Cladophlebis nebbensis KRAM-P PM 139/159 (Huta OP-1, 76.4 m); 5-Cladophlebis sp. KRAM-P PM 138/25/VIII (Studzianna, 783.0 m); 6 - Todites pinceps KRAM-P PM 139/322A (Huta OP-1,97.3 m); 7 -Todites pinceps KRAM-P PM 139/322B; 8 -?Thaumatopteris sp. KRAM-P PM 139/219 (Huta OP$1,106.4 \mathrm{~m})$ 

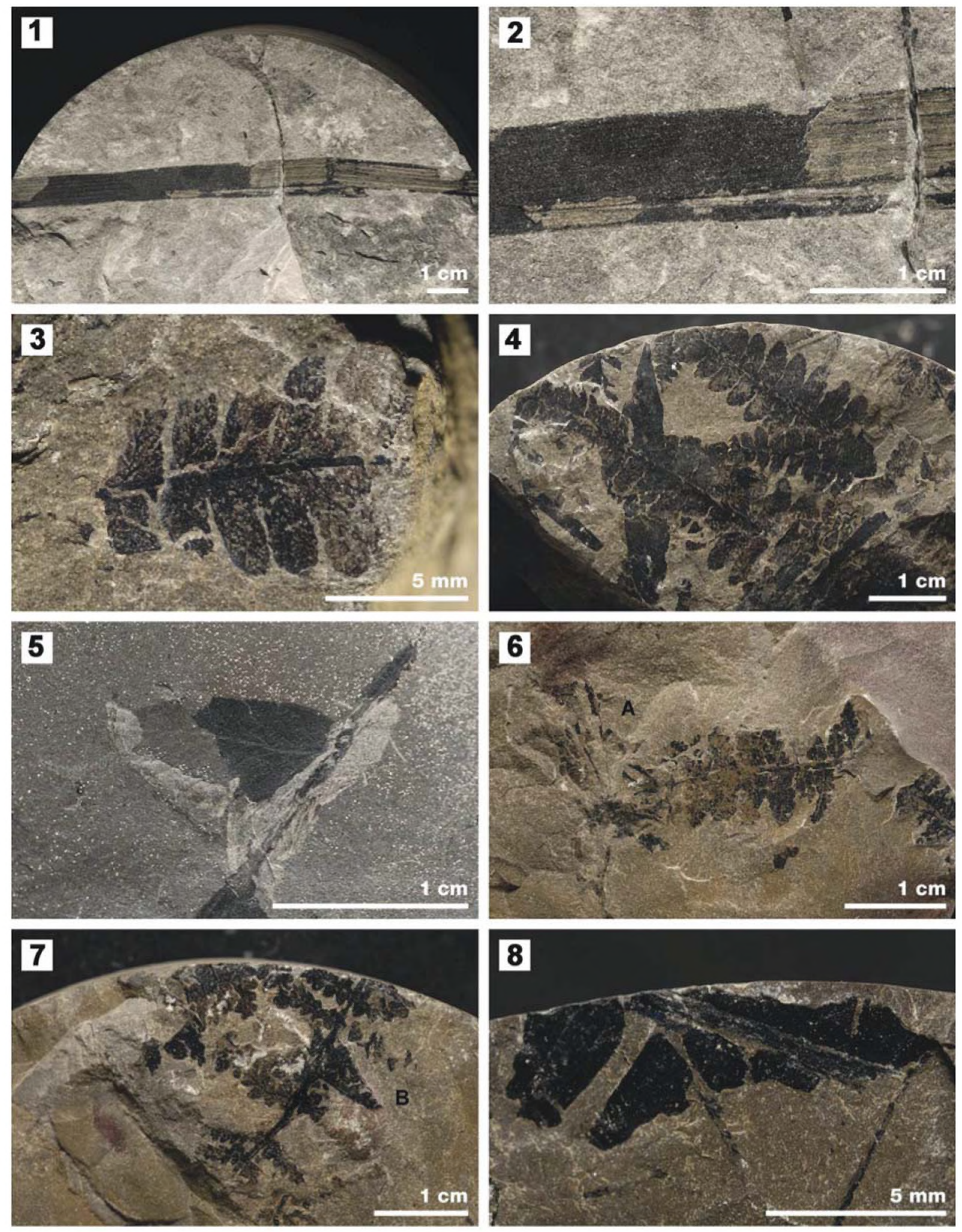


\section{PLATE 3}

1 - Phlebopteris angustiloba KRAM-P PM 139/326 (Huta OP-1, 182.9 m); 2 - Phlebopteris muensteri Muz. Geol. PIG 1794.II.2 (Ciechocinek, 972.7); 3 - Phlebopteris muensteri Muz. Geol. PIG 1794.II.2, detail; 4 - Coniopteris hymenophylloides fertile frond KRAM-P PM 139/106 (Huta OP-1, 73.9 m); 5 - Coniopteris hymenophylloides sterile frond KRAM-P PM 139/104 (Huta OP-1, 73.9 m); 6-Lepidopteris ottonis Muz. Geol. PIG 1794.II, Muz. Geol. PIG 1794.II.5 (Chabowo 2, 1220.4 m); 7 - Lepidopteris ottonis Muz. Geol. PIG 1794.II, Muz. Geol. PIG 1794.II.5, stomata on the lower cuticle; 8 - Pachypteris sp. Muz. Geol. PIG 1794.II.2 (Brześć Kujawski IG 3, $2190.0 \mathrm{~m})$ 

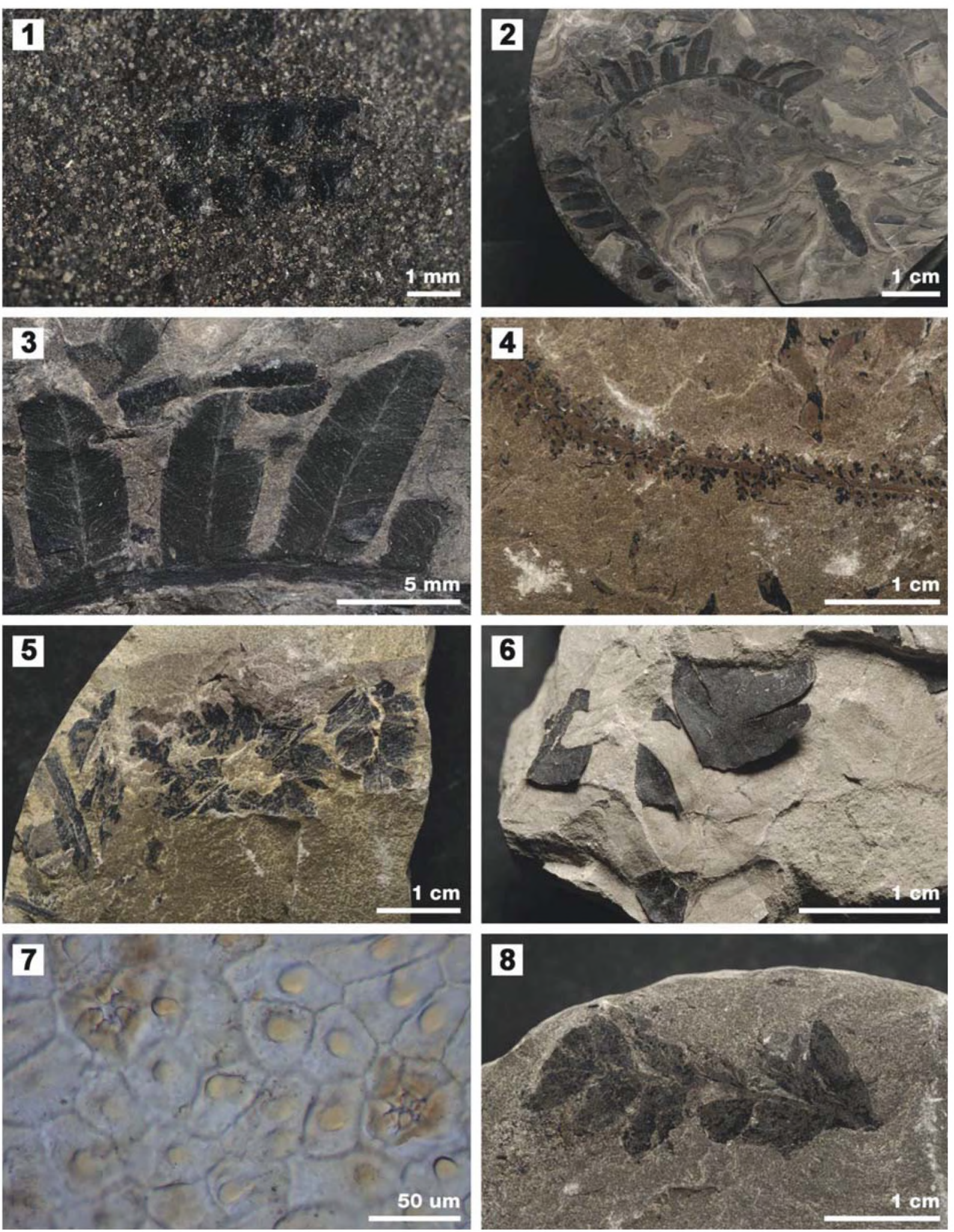


\section{PLATE 4}

1 - Ginkgoites cf. marginatus KRAM-P PM 138/48/II, lower cuticle (Studzianna, 980.0 m); 2 - Ginkgoites cf. marginatus KRAM-P PM 138/48/II, lower cuticle, stomata; 3 - Ginkgoites cf. marginatus KRAM-P PM 138/48/II, upper cuticle, resin body; 4-Ginkgoites cf. marginatus KRAM-P PM 138/48/II; 5 - Ginkgoites sp. KRAM-P PM 138/84 (Studzianna, 862.0 m); 6 - Ginkgoites sp. KRAM-P PM 138/84, fragment of the cuticle; 7 - Baiera furcata KRAM-P PM 139/4 (Huta OP-1, 71.2 m); 8-Baiera furcata KRAM-P PM 139/4, lower cuticle 

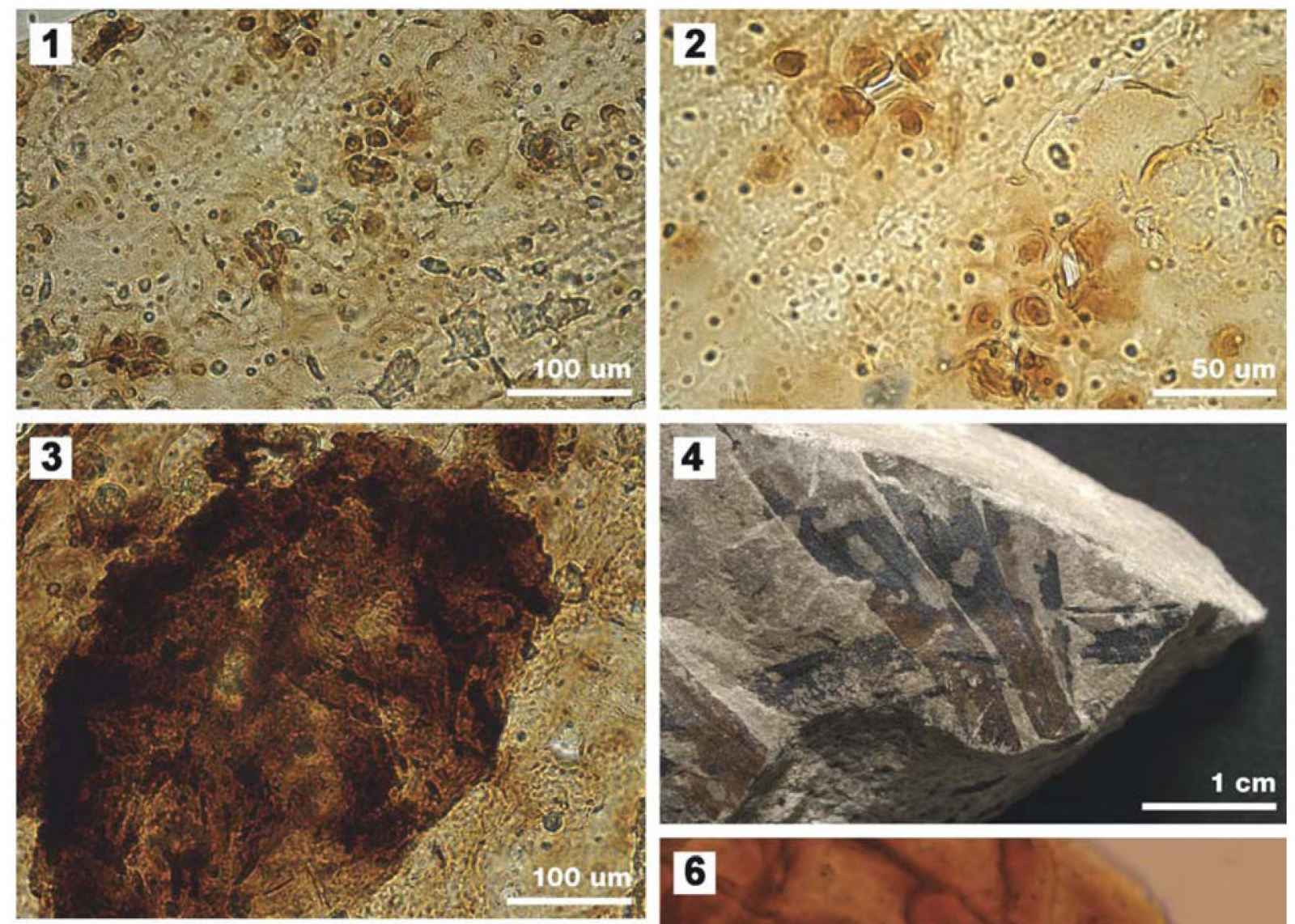

\section{6}
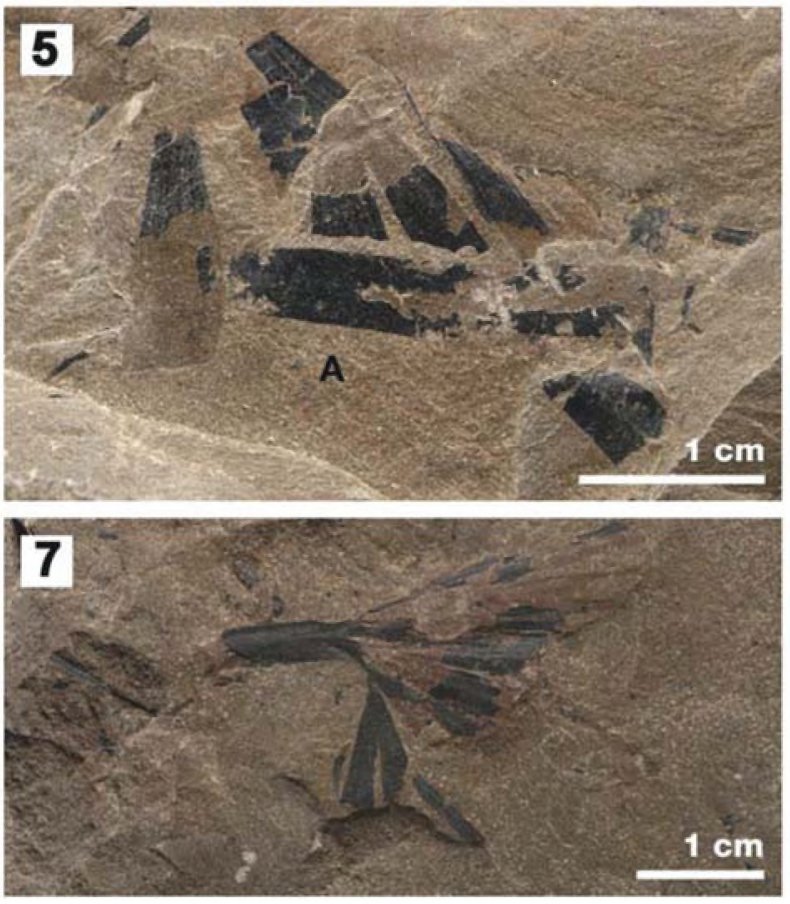

50 um

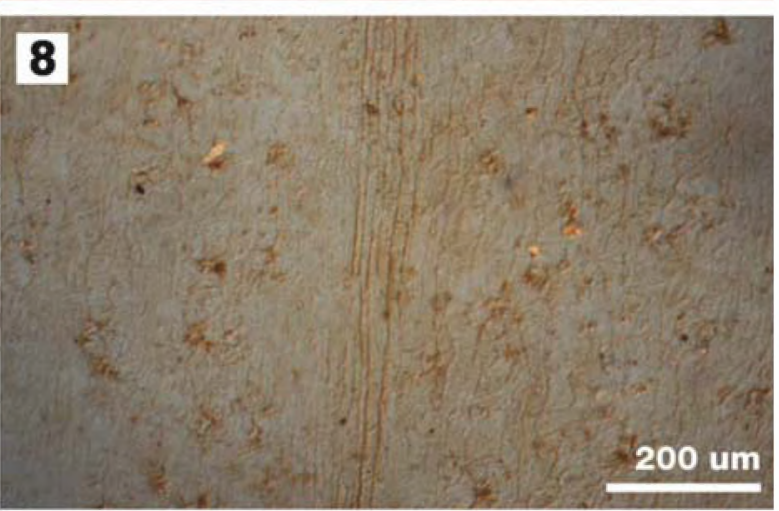




\section{PLATE 5}

1 - Baiera furcata KRAM-P PM 139/4, upper cuticle (Huta OP-1, 71.2 m); 2 - Baiera furcata KRAM-P PM 139/4, lower cuticle, stomata; 3 - Baiera furcata KRAM-P PM 139/4, lower cuticle details of stomata; 4 - ?Baiera sp. KRAM-P PM 139/296B (Huta OP-1, 72.9 m); 5 - ?Baiera sp. KRAM-P PM 139/296B, lower cuticle resin body; 6 - ?Baiera sp. KRAM-P PM 139/301A, lower cuticle (Huta OP-1, 72.9 m); 7 - ?Baiera sp. KRAM-P PM 139/301A, stomata; 8 - ?Baiera sp. KRAM-P PM 139/301A, lower/upper cuticle 

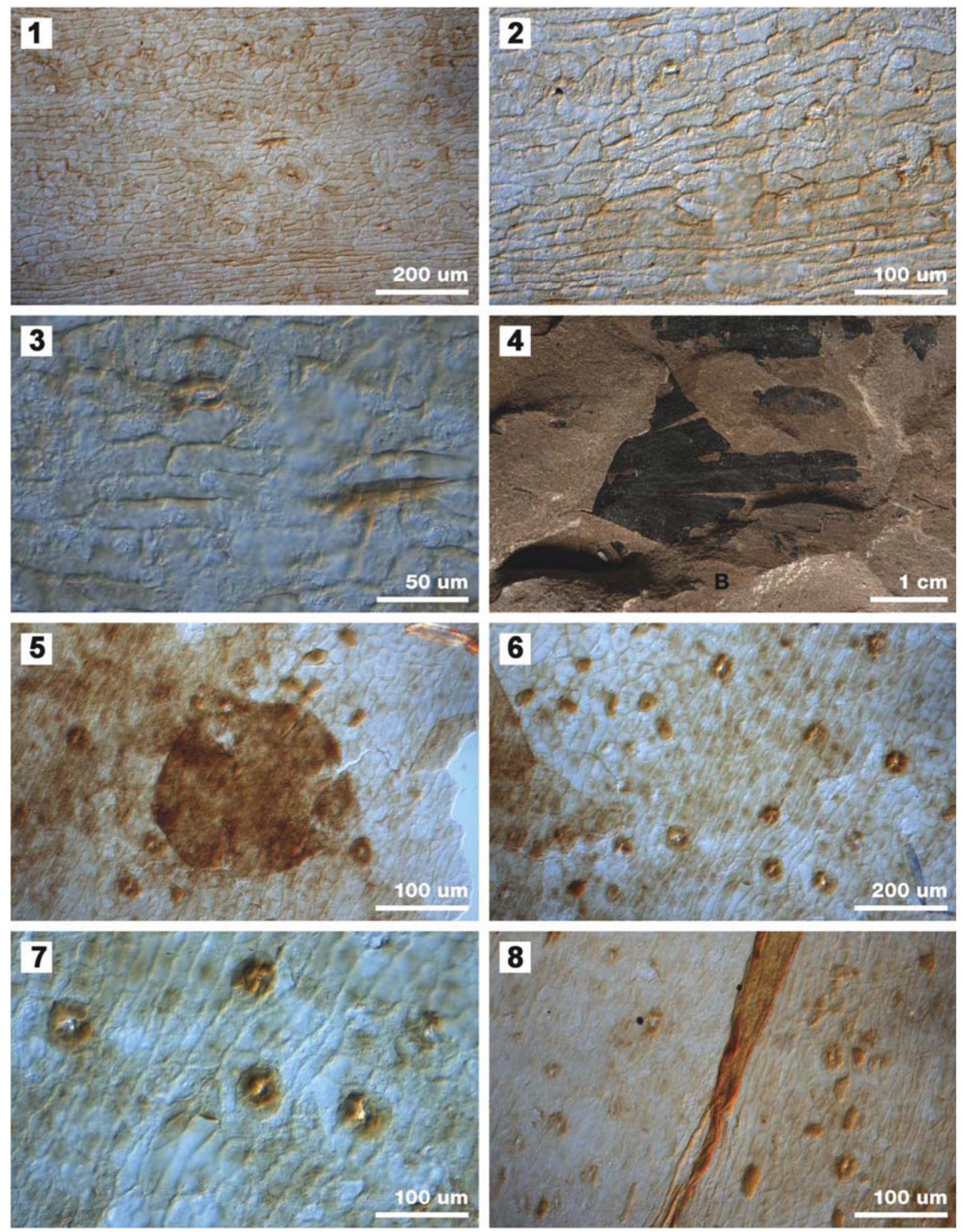


\section{PLATE 6}

1 - ?Baiera sp. KRAM-P PM 139/301A details of stomata (Huta OP-1, $72.9 \mathrm{~m}$ ); 2 - Pseudotorellia nordenskioeldii KRAM-P PM 138/25/IIA (Studzianna, 783.0 m); 3 - Pseudotorellia nordenskioeldii KRAM-P PM 138/25/IIA, detail of venation; 4 - Pseudotorellia nordenskioeldii KRAM-P PM 138/25/IIA, lower cuticle; 5 - Pseudotorellia nordenskioeldii KRAM-P PM 138/25/IIA, lower cuticle, details of stomata; 6-Pseudotorellia nordenskioeldii KRAM-P PM 138/25/IIA, upper cuticle; 7 - Pseudotorellia nordenskioeldii KRAM-P PM 138/25/IIA, lower/upper cuticle; 8 - Pseudotorellia sp., KRAM-P PM 139/159 (Huta OP-1, 76.4 m) 

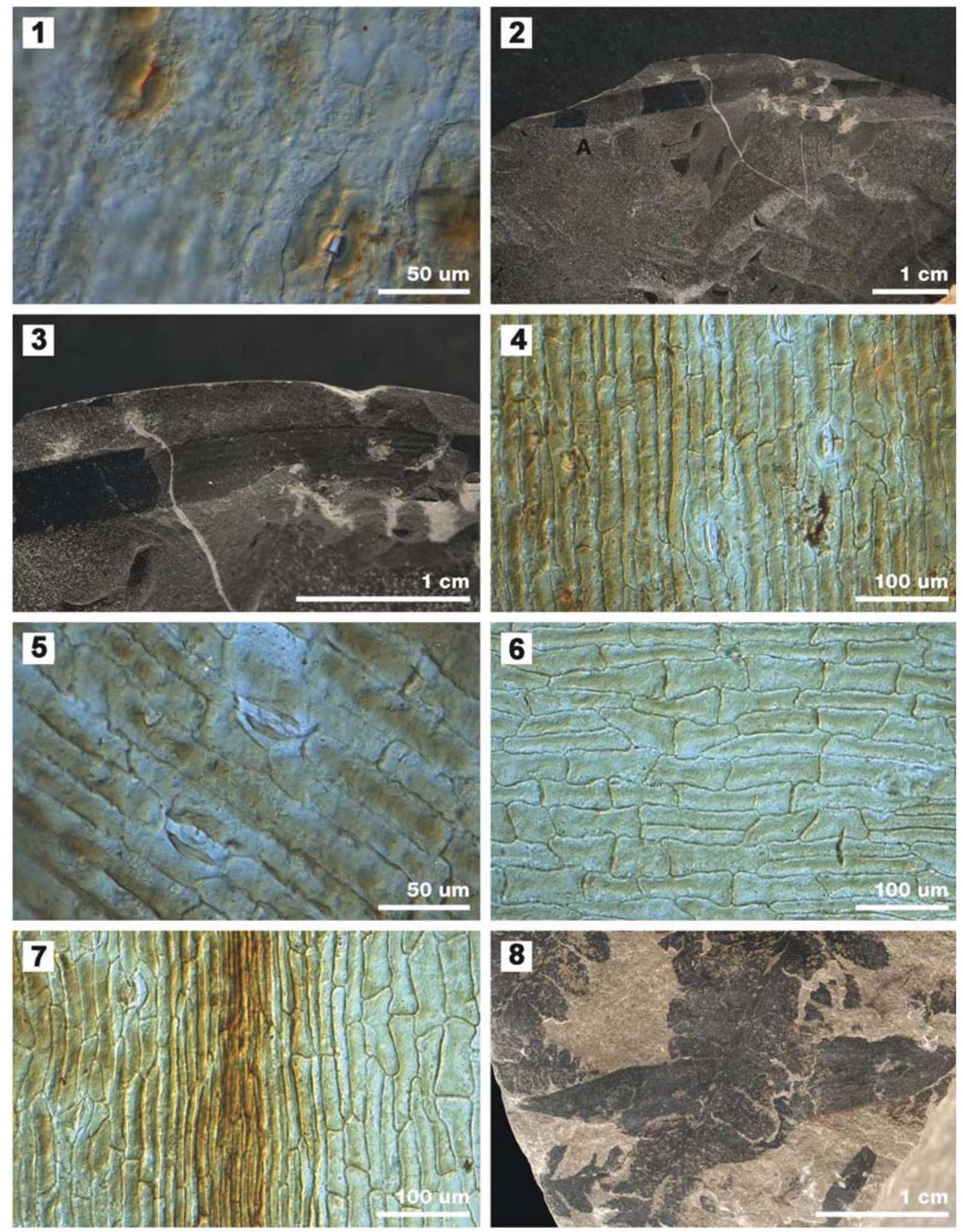


\section{PLATE 7}

1 - Pseudotorellia sp., KRAM-P PM 139/159, details of venation (Huta OP-1, 76.4 m); 2 - Czekanowskia hartzii, KRAM-P PM 138/8A-B (Studzianna, $862.0 \mathrm{~m}$ ); 3 -Czekanowskia hartzii, KRAM-P PM 138/8A-B, lower cuticle, distribution of stomata; 4 - Czekanowskia hartzii, KRAM-P PM 138/8A-B, upper cuticle; 5 -Czekanowskia hartzii, KRAM-P PM 138/8A-B, lower cuticle, details of stomata; 6 - Czekanowskia rigida, KRAM-P PM 138/39B (Studzianna, $980.0 \mathrm{~m}$ ); 7 - Czekanowskia rigida, KRAM-P PM 138/39B, lower cuticle; 8 -Czekanowskia rigida, KRAM-P PM 138/39B, lower cuticle details of stomata 

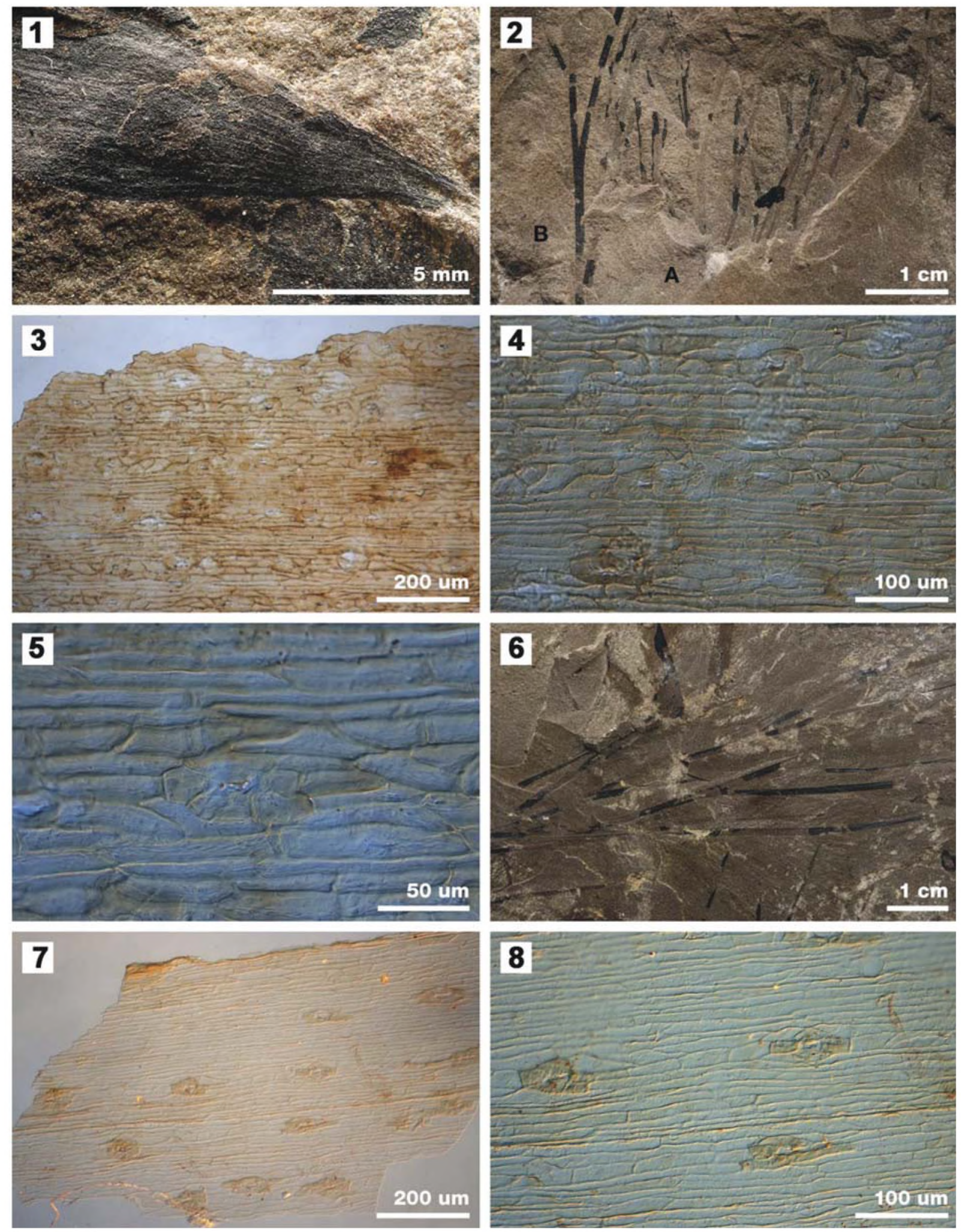


\section{PLATE 8}

1 - Czekanowskia rigida, KRAM-P PM 138/39B, lower cuticle details of stomata (Studzianna, 980.0 m); 2 - Phoenicopsis insolita, KRAM-P PM 138/70B (Studzianna, $1014.0 \mathrm{~m}) ; 3$ - Phoenicopsis insolita, KRAM-P PM 138/70B, lower cuticle; 4 - Phoenicopsis insolita, KRAM-P PM 138/70B, lower cuticle, stomata; 5 - Phoenicopsis insolita, KRAM-P PM 138/70B, upper cuticle; 6 - Phoenicopsis insolita, KRAM-P PM 138/70B, lower cuticle, details of stomata; 7 -Ixostrobus grenlandicus KRAM-P PM 139/270 (Huta OP-1, 72.2-73.4 m); 8 - Ixostrobus grenlandicus KRAM-P PM 139/270, detail 

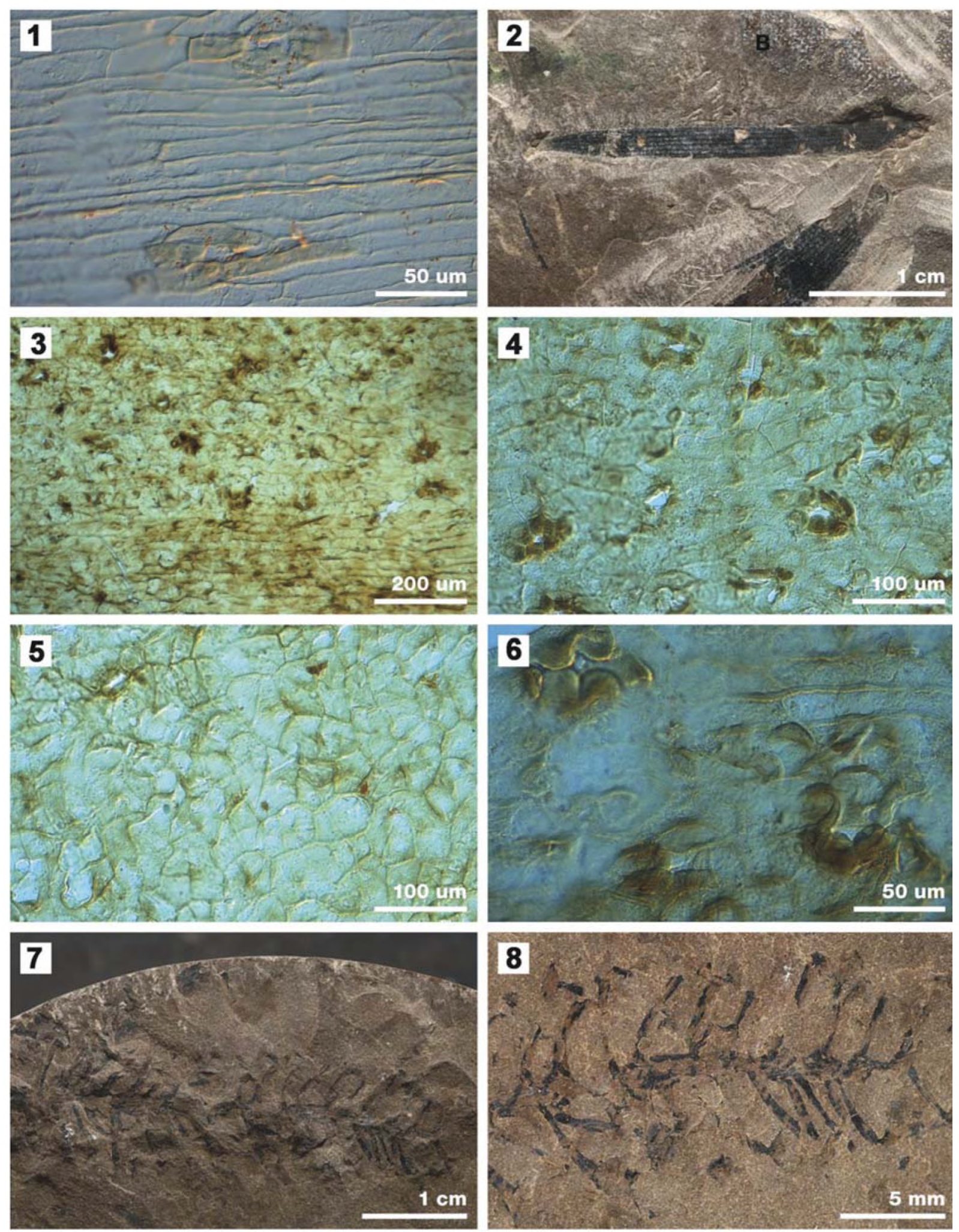


\section{PLATE 9}

1 - Podozamites distans KRAM-P PM 139/92, large form (Huta OP-1, 73.0 m);

2 - Podozamites distans KRAM-P PM 139/161, small form (Huta OP-1, $76.4 \mathrm{~m}$ ); 3 - Brachyphyllum sp. KRAM-P PM 139/206B (Huta OP-1, 137.1 m); 4-Brachyphyllum sp. KRAM-P PM 139/206B, lower cuticle; 5 - Brachyphyllum sp. KRAM-P PM 139/206B, lower cuticle, details of stomata; 6-Desmiophyllum harrisii, KRAMP PM 139/110, type specimen (Huta OP-1, 67.0 m); 7 - Desmiophyllum harrisii, KRAM-P PM 139/110, type specimen, detail of venation; 8 -Desmiophyllum harrisii, KRAM-P PM 139/110, upper cuticle 

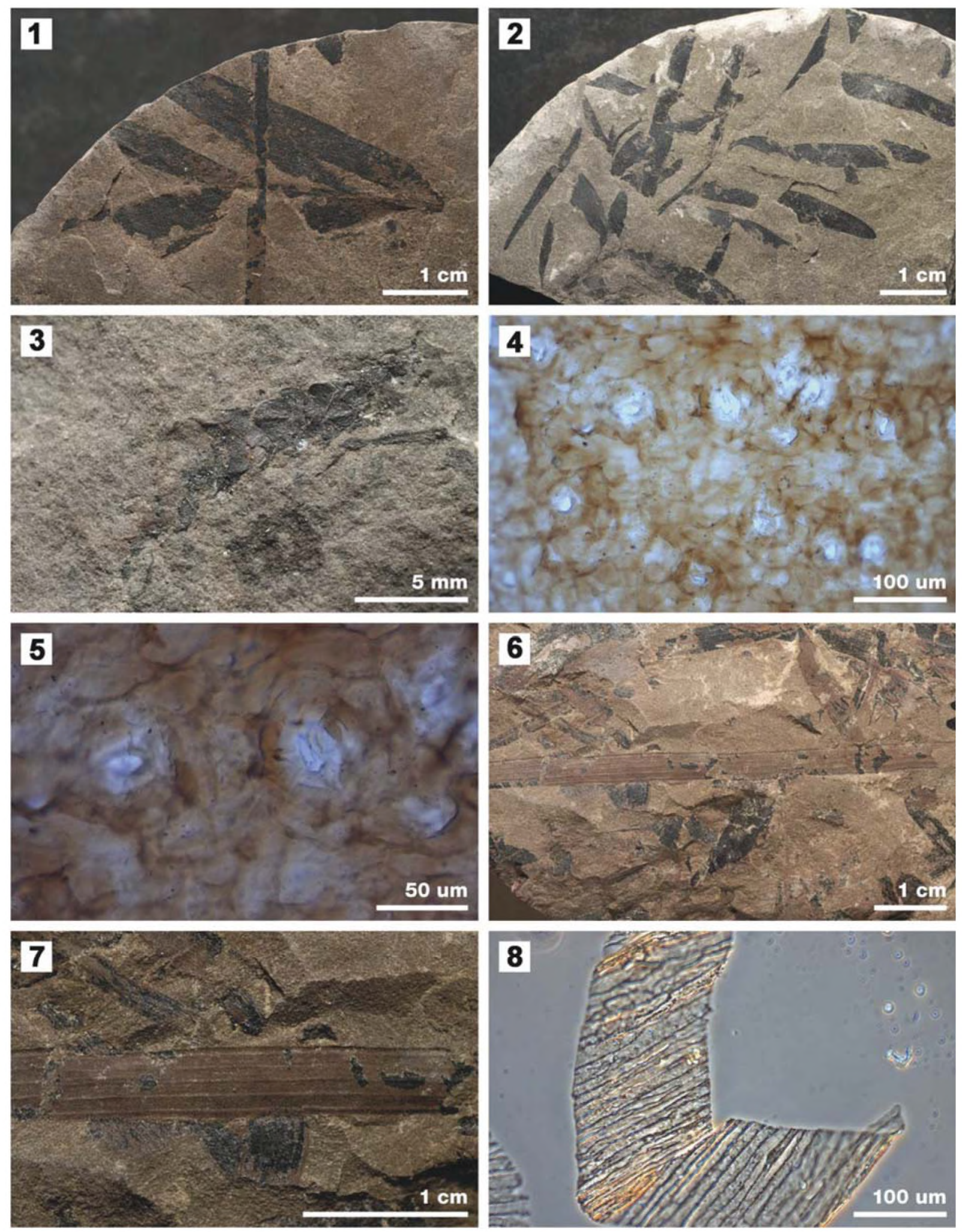